\title{
House dust mite reduction and avoidance measures for treating eczema (Review)
}

Nankervis H, Pynn EV, Boyle RJ, Rushton L, Williams HC, Hewson DM, Platts-Mills T

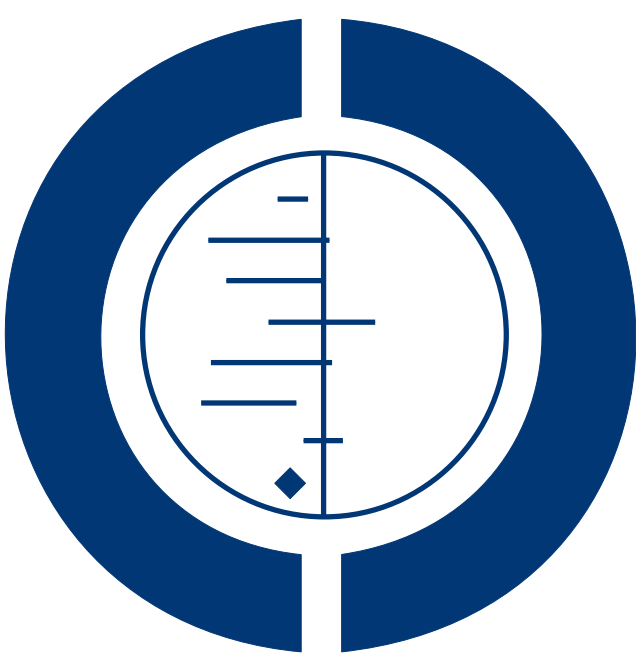

\section{THE COCHRANE COLLABORATION $^{\circledR}$}

This is a reprint of a Cochrane review, prepared and maintained by The Cochrane Collaboration and published in The Cochrane Library 2015, Issue 1

http://www.thecochranelibrary.com

\section{WILEY}

House dust mite reduction and avoidance measures for treating eczema (Review)

Copyright @ 2015 The Cochrane Collaboration. Published by John Wiley \& Sons, Ltd. 
TABLE OF CONTENTS

HEADER . . . . . . . . . . . . . . . . . . . . . . . . . . . . . . . . . . . . 1

ABSTRACT . . . . . . . . . . . . . . . . . . . . . . . . . . . . . . . . . . . . . . . . . . . . . . .

PLAIN LANGUAGE SUMMARY . . . . . . . . . . . . . . . . . . . . . . . . . . . . . . . . . . . . . . . . .

SUMMARY OF FINDINGS FOR THE MAIN COMPARISON $\quad . \quad$. . . . . . . . . . . . . . . . . . . . . . . . . 4.4

BACKGROUND . . . . . . . . . . . . . . . . . . . . . . . . . . . . . . . . . . . . . 5

Figure 1. . . . . . . . . . . . . . . . . . . . . . . . . . . . . . . . . . . . . . .

Figure 2. . . . . . . . . . . . . . . . . . . . . . . . . . . . . . . . . . . . . . 8

OBJECTIVES . . . . . . . . . . . . . . . . . . . . . . . . . . . . . . . . . . . . . . .

METHODS . . . . . . . . . . . . . . . . . . . . . . . . . . . . . . . . . . . 9

RESULTS . . . . . . . . . . . . . . . . . . . . . . . . . . . . . . . . . . . . . . . 12

Figure 3. . . . . . . . . . . . . . . . . . . . . . . . . . . . . . . . . . . . . . 13

Figure $4 . \quad$. . . . . . . . . . . . . . . . . . . . . . . . . . . . . . . . . . . . . 16

DISCUSSION . . . . . . . . . . . . . . . . . . . . . . . . . . . . . . . . . . . . . . . . . . . . . .

AUTHORS' CONCLUSIONS . . . . . . . . . . . . . . . . . . . . . . . . . . . . . . . . . . . . .

ACKNOWLEDGEMENTS . . . . . . . . . . . . . . . . . . . . . . . . . . . . . . . . . 20

REFERENCES . . . . . . . . . . . . . . . . . . . . . . . . . . . . . . . . . . . . . . 21

CHARACTERISTICS OF STUDIES . . . . . . . . . . . . . . . . . . . . . . . . . . . . . . . . . . . . . . . .

DATA AND ANALYSES . . . . . . . . . . . . . . . . . . . . . . . . . . . . . . . . . . . . 34

CONTRIBUTIONS OF AUTHORS . . . . . . . . . . . . . . . . . . . . . . . . . . . . . . . . . . . . . . .

DECLARATIONS OF INTEREST . . . . . . . . . . . . . . . . . . . . . . . . . . . . . . . . . . . . . . . . . .

SOURCES OF SUPPORT . . . . . . . . . . . . . . . . . . . . . . . . . . . . . . . . . . . . . . . . . . . . . . .

DIFFERENCES BETWEEN PROTOCOL AND REVIEW . . . . . . . . . . . . . . . . . . . . . . 35 


\title{
[Intervention Review] \\ House dust mite reduction and avoidance measures for treating eczema
}

\author{
Helen Nankervis ${ }^{1}$, Emma V Pynn ${ }^{2}$, Robert J Boyle ${ }^{3}$, Lesley Rushton ${ }^{4}$, Hywel C Williams ${ }^{1}$, Deanne M Hewson ${ }^{5}$, Thomas Platts-Mills \\ ${ }^{1}$ Centre of Evidence Based Dermatology, The University of Nottingham, Nottingham, UK. ${ }^{2}$ Department of Dermatology, University \\ Hospital of Wales, Cardiff, UK. ${ }^{3}$ Allergy and Infectious Diseases, Section of Paediatrics, Division of Infectious Diseases, Department of \\ Medicine, Imperial College London, London, UK. ${ }^{4}$ Department of Epidemiology and Biostatistics, Imperial College London, London, \\ UK. ${ }^{5}$ c/o Cochrane Skin Group, The University of Nottingham, Nottingham, UK. ${ }^{6}$ Department of Medicine, Division of Asthma, \\ Allergy and Immunology, University of Virginia, Charlottesville, Virginia, USA \\ Contact address: Helen Nankervis, Centre of Evidence Based Dermatology, The University of Nottingham, A103, King's Meadow \\ Campus, Lenton Lane, Nottingham, NG7 2NR, UK. helen.nankervis@nottingham.ac.uk.
}

Editorial group: Cochrane Skin Group.

Publication status and date: New, published in Issue 1, 2015.

Review content assessed as up-to-date: 14 August 2014.

Citation: Nankervis H, Pynn EV, Boyle RJ, Rushton L, Williams HC, Hewson DM, Platts-Mills T. House dust mite reduction and avoidance measures for treating eczema. Cochrane Database of Systematic Reviews 2015, Issue 1. Art. No.: CD008426. DOI: 10.1002/14651858.CD008426.pub2.

Copyright (C) 2015 The Cochrane Collaboration. Published by John Wiley \& Sons, Ltd.

\begin{abstract}
A B S T R A C T
Background

Eczema is an inflammatory skin disease that tends to involve skin creases, such as the folds of the elbows or knees; it is an intensely itchy skin condition, which can relapse and remit over time. As many as a third of people with eczema who have a positive test for allergy to house dust mite have reported worsening of eczema or respiratory symptoms when exposed to dust.
\end{abstract}

\section{Objectives}

To assess the effects of all house dust mite reduction and avoidance measures for the treatment of eczema.

\section{Search methods}

We searched the following databases up to 14 August 2014: the Cochrane Skin Group Specialised Register, CENTRAL in The Cochrane Library (2014, Issue 8), MEDLINE (from 1946), Embase (from 1974), LILACS (from 1982), and the GREAT database. We also searched five trials registers and checked the reference lists of included and excluded studies for further references to relevant studies. We handsearched abstracts from international eczema and allergy meetings.

\section{Selection criteria}

Randomised controlled trials (RCTs) of any of the house dust mite reduction and avoidance measures for the treatment of eczema, which included participants of any age diagnosed by a clinician with eczema as defined by the World Allergy Organization. We included all non-pharmacological and pharmacological interventions that sought to reduce or avoid exposure to house dust mite and their allergenic faeces. The comparators were any active treatment, no treatment, placebo, or standard care only.

\section{Data collection and analysis}

Two authors independently checked the titles and abstracts identified, and there were no disagreements. We contacted authors of included studies for additional information. We assessed the risk of bias using Cochrane methodology.

House dust mite reduction and avoidance measures for treating eczema (Review)

Copyright $\odot 2015$ The Cochrane Collaboration. Published by John Wiley \& Sons, Ltd. 


\section{Main results}

We included seven studies of 324 adults and children with eczema. Overall, the included studies had a high risk of bias. Four of the seven trials tested interventions with multiple components, and three tested a single intervention. Two of the seven trials included only children, four included children and adults, and one included only adults. Interventions to reduce or avoid exposure to house dust mite included covers for mattresses and bedding, increased or high-quality vacuuming of carpets and mattresses, and sprays that kill house dust mites.

Four studies assessed our first primary outcome of 'Clinician-assessed eczema severity using a named scale'. Of these, one study $(\mathrm{n}=20)$ did not show any significant short-term benefit from allergen impermeable polyurethane mattress encasings and acaricide spray versus allergen permeable cotton mattress encasings and placebo acaricide spray. One study $(n=60)$ found a modest statistically significant benefit in the Six Area, Six Sign Atopic Dermatitis (SASSAD) scale over six months (mean difference of 4.2 ( $95 \%$ confidence interval 1.7 to 6.7$), P=0.008$ ) in favour of a mite impermeable bedding system combined with benzyltannate spray and high-filtration vacuuming versus mite permeable cotton encasings, water with a trace of alcohol spray, and a low-filtration vacuum cleaner. The third study ( $\mathrm{n}$ = 41) did not compare the change in severity of eczema between the two treatment groups. The fourth study $(\mathrm{n}=86)$ reported no evidence of a difference between the treatment groups.

With regard to the secondary outcomes 'Participant- or caregiver-assessed global eczema severity score' and the 'Amount and frequency of topical treatment required', one study $(\mathrm{n}=20)$ assessed these outcomes with similar results being reported for these outcomes in both groups. Four studies $(n=159)$ assessed 'Sensitivity to house dust mite allergen using a marker'; there was no clear evidence of a difference in sensitivity levels reported between treatments in any of the four trials.

None of the seven included studies assessed our second primary outcome 'Participant- or caregiver-assessed eczema-related quality of life using a named instrument' or the secondary outcome of 'Adverse effects'.

We were unable to combine any of our results because of variability in the interventions and paucity of data.

\section{Authors' conclusions}

We were unable to determine clear implications to inform clinical practice from the very low-quality evidence currently available. The modest treatment responses reported were in people with atopic eczema, specifically with sensitivity to one or more aeroallergens. Thus, their use in the eczema population as a whole is unknown. High-quality long-term trials of single, easy-to-administer house dust mite reduction or avoidance measures are worth pursuing.

\section{PLAIN LANGUAGE SUMMARY}

\section{House dust mite reduction and avoidance measures for treating eczema}

\section{Background}

Eczema is an intensely itchy skin disease that tends to involve skin creases, such as the folds of the elbows or knees. It is a worldwide problem affecting 5\% to $20 \%$ of children. Around $2 \%$ of adults have the condition, and many have a more chronic and severe form. As many as a third of people with eczema who have a positive test for allergy to house dust mite have reported worsening of eczema or respiratory symptoms when exposed to dust. Ways to reduce or avoid exposure to house dust mite, such as covers for mattresses and bedding, increased or high-quality vacuuming of carpets and mattresses, or sprays that kill the mites, could lessen the severity of eczema for those who are sensitive to house dust mite. In this review, we aimed to assess the effects of all house dust mite reduction and avoidance measures for the treatment of eczema.

\section{Review question}

Do house dust reduction and avoidance measures provide a successful way to treat eczema?

\section{Study characteristics}

We found seven randomised controlled trials, which included 324 adults and children with eczema. We conducted the search up to 14 August 2014. Two of the seven trials included only children; four included children and adults; and one only included adults. Four of the seven trials compared treatments made up of multiple different house dust mite reduction and avoidance measures, and three trials tested a single treatment. The treatments were compared against other house dust mite reduction or avoidance treatments, no treatment, a placebo intervention (e.g., cotton bed covers), or standard care only.

House dust mite reduction and avoidance measures for treating eczema (Review)

Copyright $\odot 2015$ The Cochrane Collaboration. Published by John Wiley \& Sons, Ltd. 


\section{Key results}

We did not find any evidence to inform clinical practice. Some small treatment responses reported were in people with atopic eczema who were sensitive to one or more airborne allergens. We found no evidence of benefit in the other six included studies. Therefore, their use in the eczema population as a whole is unknown. High-quality longer trials of single, easy-to-use house dust mite reduction or avoidance measures should be performed.

\section{Quality of the evidence}

These seven very low-quality (Grading of Recommendations Assessment, Development and Evaluation (GRADE) approach) small trials do not provide enough evidence to recommend any of the house dust mite reduction and avoidance measures tested. 
SUMMARY OF FINDINGS FOR THE MAIN COMPARISON [Explanation]

\begin{tabular}{|c|c|c|c|}
\hline \multicolumn{4}{|c|}{$\begin{array}{l}\text { Patient or population: children and adults with eczema with proven sensitivity to house dust mite } \\
\text { Settings: participant's home } \\
\text { Intervention: active } \\
\text { Comparison: control }\end{array}$} \\
\hline Outcomes & $\begin{array}{l}\text { Number of Participants } \\
\text { (studies) }\end{array}$ & $\begin{array}{l}\text { Quality of the evidence } \\
\text { (GRADE) }\end{array}$ & Comments \\
\hline $\begin{array}{l}\text { Clinician-assessed global } \\
\text { eczema severity using a named } \\
\text { scale (Leicester Sign Score) }\end{array}$ & $86(1)$ & $\oplus \bigcirc \bigcirc \bigcirc$ very low $^{a}$ & Oosting $2002^{1}$ \\
\hline $\begin{array}{l}\text { Clinician-assessed global } \\
\text { eczema severity using a named } \\
\text { scale (SASSAD) }\end{array}$ & $60(1)$ & $\oplus \bigcirc \bigcirc \bigcirc$ very low $b$ & $\operatorname{Tan} 1996^{2}$ \\
\hline $\begin{array}{l}\text { Clinician-assessed global } \\
\text { eczema severity using a named } \\
\text { scale (SCORAD) }\end{array}$ & $61(2)$ & $\oplus \bigcirc \bigcirc \bigcirc$ very low ${ }^{c}$ & Gutgesell 20013; Ricci 20004 \\
\hline $\begin{array}{l}\text { Participant- or caregiver-as- } \\
\text { sessed eczema-related quality of } \\
\text { life (named instrument) }\end{array}$ & $0(0)$ & $\mathrm{N} / \mathrm{A}$ & - \\
\hline
\end{tabular}

GRADE Working Group grades of evidence

High quality: Further research is very unlikely to change our confidence in the estimate of effect.

Moderate quality: Further research is likely to have an important impact on our confidence in the estimate of effect and may change the estimate.

Low quality: Further research is very likely to have an important impact on our confidence in the estimate of effect and is likely to change the estimate.

Very low quality: We are very uncertain about the estimate.

${ }^{a}$ Reasons for a rating of very low quality: moderate proportions of participants not analysed (losses to follow up); not clear whether the severity of eczema outcome assessors were blinded or not; severity of eczema was not analysed between treatment groups; the total Leicester Sign Score (LSS) data not reported, including no analyses.

${ }^{b}$ Reasons for a rating of very low quality: big differential in the proportions of participants who were not included in the analyses, small numbers of participants, baseline severity scores are very different, with the active treatment group having a higher baseline severity and it is unclear whether this was adjusted for in the analyses.

${ }^{c}$ Reasons for a rating of very low quality: differences in baseline severity, with the active group being more severe, for which it is unclear whether this was adjusted for in the analyses; small numbers of participants in both trials.

10osting 2002

Active interventions: mite impermeable encasings for mattress, pillow, and duvet.

Control interventions: mite permeable encasings for mattress, pillow, and duvet.

Results: active treatment group (LSS disease activity 17 (6 to 60) to 13 (0 to 55), $\mathrm{P}=0.017$ ) (LSS extent 19.5 (3 to 88) to 14.5 (0 to 87), $P=0.038$ ) (LSS itching score $\mathrm{mm} 73.5$ (0 to 100) to 63 (4 to 100), $P=0.045$ ), but did not report the total LSS scores. The trial report mentioned that there were no significant between-group differences, but did not report any more detail.

2Tan 1996

House dust mite reduction and avoidance measures for treating eczema (Review)

Copyright @ 2015 The Cochrane Collaboration. Published by John Wiley \& Sons, Ltd. 
Active interventions: mite impermeable encasings, acaricide spray on carpets, and high-filtration vacuum cleaner.

Control interventions: mite permeable encasings, water with a trace of alcohol spray on carpets, and standard-filtration vacuum cleaner. Results: mean differences in the mean severity scores were -12.6 in the active treatment group and -4.2 in the control group. The analysis of the differences in the reduction in severity scores between groups used analysis of covariance with initial eczema scores and logs of the initial mattress dust weight and bedroom carpet Der 1 1 (Dermatophagoides pteronyssinus) concentration as covariates and reported a mean difference of 4.2 ( $95 \%$ confidence interval $(\mathrm{Cl}) 1.7$ to 6.7 ), $\mathrm{P}=0.008$ (unpaired student's t-test) in favour of the GORETEX® bedding system, benzyltannate spray, and high-filtration vacuuming.

${ }^{3}$ Gutgesell 2001

Active interventions: allergen impermeable encasings, acaricide spray (tannic acid and benzyl benzoate).

Control interventions: allergen permeable encasings, water with a trace of ethanol spray.

Results: no statistically significant difference in reduction of severity after one year $(P=0.901)$ (non-parametric tests for tests of repeated measures) between the treatment groups. The active encasings group had a reduction in SCORing Atopic Dermatitis (SCORAD) from a median (interquartile range) of 46 (37 to 55) to 40 (32 to 63), and the control encasings had a change from 35 (24 to 46 ) to 37 (30 to 45 ). This study did not provide many details; the SCORAD scores were abstracted from a graph.

${ }^{4}$ Ricci 2000

Active interventions: mite impermeable encasings for mattresses and pillows, weekly hot wash of bedding, frequent vacuuming of living room and bedroom, soft toys and carpets regularly cleaned or removed, no pets allowed.

Control interventions: no recommendations for changing cleaning patterns given (no treatment).

Results: The reduction in severity was recorded within the group using the dust mite avoidance measures (a reduction from a mean of 33 to 26 SCORAD points) and the group who used normal cleaning patterns (a reduction from a mean of 27 to 24 SCORAD points); however, the change in severity of eczema was not compared between the two groups.

\section{B A C K G R O U N D}

\section{Description of the condition}

\section{Disease definition}

Eczema is an inflammatory skin disease that tends to involve flexural skin creases, such as the folds of the elbows or knees. Eczema is an intensely itchy skin condition, which can relapse and remit over time (Williams 1994).

Eczema is also often called atopic dermatitis or atopic eczema. The nomenclature for allergy (Johansson 2001) has been revised and is now based on the mechanisms by which allergic reactions are initiated and mediated, although this nomenclature has not yet been universally adopted. The term atopic eczema can only be used when sensitisation to common allergens has been verified by identifying immunoglobulin $\mathrm{E}$ ( $\mathrm{IgE}$ ) antibodies in the blood or by a positive skin prick test (Johansson 2004). We have used the term eczema in this review throughout to refer to what is usually described as atopic dermatitis or atopic eczema. We have only used the terms atopic eczema and atopic dermatitis when IgE sensitisation has been confirmed. No clinical relevance for diagnosis between proven atopic eczema and non-atopic eczema has yet been found (Flohr 2004).

See Figure 1 for an example of this condition.

House dust mite reduction and avoidance measures for treating eczema (Review) 
Figure I. Acute atopic eczema in a child. Copyright $\odot 1991$ Professor Hywel Williams: reproduced with permission

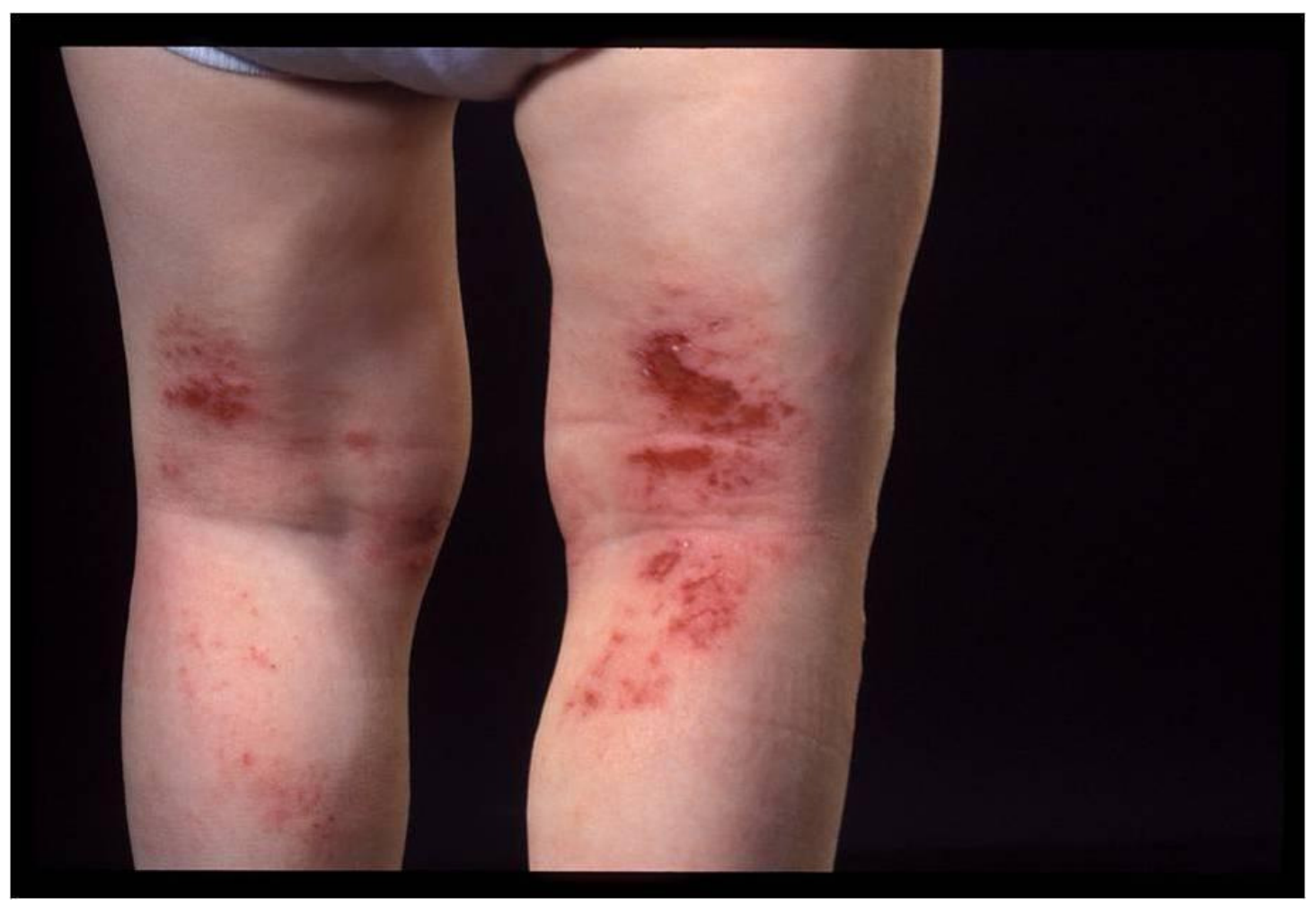

\section{Epidemiology and causes}

Eczema is a worldwide problem affecting $5 \%$ to $20 \%$ of children (Williams 1999). Many of the approximately $2 \%$ of adults with eczema have to cope with a more severe and longer lasting form of the condition (Charman 2000a). The prevalence of eczema varies considerably between and within countries (Williams 1999). Of the children with eczema in the UK under the age of five years old, around $2 \%$ have severe disease, and $84 \%$ have mild disease (Emerson 1998).

Eczema is a complex disease, which probably depends on a complex interaction between several genetic and environmental factors. Recently, a genetic defect that affects the production of a key protein for skin barrier function (filaggrin gene mutation) has been linked to an increased risk of atopic eczema (eczema with IgE sensitisation) (Muller 2009; van den Oord 2009). External factors, including house dust mites (Van Bever 2002), microbes (Bjorksten 2001), climate, stress, and air pollution (Brauer 2007; Penard -Mornard 2005), have all been associated with an altered risk of developing eczema (Langan 2006). People with severe eczema tend to be sensitive to multiple indoor and outdoor allergens.

\section{Clinical features}

Acute (short-term) eczema often presents as mainly redness, collections of fluid in the top layers of the skin in the form of 'water blisters' (vesicles), and oozing. Chronic (long-term) eczema has scaling, skin thickening, altered pigmentation, and exaggerated surface markings as the predominant signs. Mild eczema often presents as localised mild scaling, ranging through to severe eczema, which generally involves the whole body, with redness, oozing, and secondary infection (Birnie 2008). Eczema mainly affects the flexural creases of the elbows and knees and the face and neck, although any part of the body can be affected. The main symptom is itching, which will often lead to a vicious cycle of scratching, damage, and more itching: the so called "itch scratch itch" cycle (Bath-Hextall 2008; Boyle 2008).

\section{Natural history}

Eczema usually develops early in childhood, with $60 \%$ of cases being seen before the age of one year old and $85 \%$ of cases seen 
before the age of five years old (Emerson 2001). The majority ( $60 \%$ to $70 \%)$ of children who have eczema will be clear by 15 years old, although some later relapse. People with eczema are also more likely to have other atopic diseases, such as asthma, rhinitis, and food allergy (Beck 2000). The tendency for people who have or have had eczema to go on to develop asthma and allergies has become known as the 'atopic march'. Whether this 'march' from one allergic disease to another exists is the subject of much speculation (Curtiss 2007; Williams 2006).

\section{Impact}

Eczema varies in severity, often from one hour to the next (Bath-Hextall 2008; Boyle 2008). Chronic sleep disturbance due to itching and scratching can result in a poor quality of life (Meltzer 2008). The social and emotional impact on the family of a child with eczema can be in excess of the impact of type I diabetes ( $\mathrm{Su}$ 1997). Bacterial and viral infections can often present as complications of eczema (McHenry 1995). A child with eczema can have their confidence affected by greasy ointments making the skin look unsightly and making them less likely to join in with sports or social events. Adults with eczema often have low self-esteem, and relationships can be hard to initiate and sustain. Everyday tasks become difficult when the skin of the hands becomes very dry, sore, and broken. (Bath-Hextall 2008; Boyle 2008). Severe eczema in childhood may lead to delayed development and puberty (Baum 2002).

Families of people with eczema (Kemp 2003) as well as a country's health service can incur substantial economic costs (Mancini 2008; Verboom 2002). Eczema has been shown to have similar healthcare costs to other diseases (Ellis 2002).

Families often pay a large proportion of the costs (some estimates put this at a third of the total costs for children under five), such as for special clothing; washing extra laundry; and (especially) house dust mite control measures, such as mattress protectors (
Emerson 2001). Indirect costs for families are also important, such as through lost working days when parents are looking after a child with eczema. The costs to society include the health professional's costs; parents who cannot seek employment; and the child who, as a result of missing school, may face employment limitations ( $\mathrm{Su}$ 1997).

\section{Description of the intervention}

The effectiveness of interventions that reduce or avoid exposure to house dust mites has been the subject of much uncertainty. A possible link between reduction of house dust mite exposure and improvement in asthma has been the subject of intensive research, but many of the trials have shown conflicting results, and there is debate about how the evidence should be interpreted (Gotzsche 2008; Platts-Mills 2008). The same effect has been proposed for eczema, as evidence has shown a link between mite sensitisation, exposure, and the severity of atopic dermatitis (Mitchell 1982; Platts-Mills 1983).

\section{House dust mites}

There are many different species of mite in house dust; however, only three of these are very common in homes throughout the world: Dermatophagoides farinae,Dermatophagoides pteronyssinus, andEuroglyphus maynei, which are found in temperate climates. In tropical climates, the mite Blomia tropicalis is often more common (Arlian 2001).

As well as the live mites, their dead bodies and faeces have also been shown to produce allergic reactions. House dust mites are dependant on the atmospheric humidity as they are $70 \%$ to $75 \%$ water by weight and maintain this by absorbing water from the air (Arlian 2001). Some of the interventions to reduce their numbers are therefore aimed at reducing the indoor humidity of dwellings. See Figure 2 for a picture of a house dust mite.

House dust mite reduction and avoidance measures for treating eczema (Review) 
Figure 2. A house dust mite. Copyright $(2013$ Professor Thomas Platts-Mills: reproduced with permission



\section{Ways to reduce or avoid exposure}

There are many different interventions used to attempt to reduce or avoid exposure to house dust mites, dead or alive, and their faeces. These can be divided into physical and chemical interventions. Physical interventions include physical barriers (e.g., mattress encasings), reducing indoor relative humidity (e.g., ventilation), changing floor covering, removing soft furnishings, vacuuming, air filters, ionisers, removal of fluffy or soft toys, heat exchangers, freezing, and washing ( 55 degrees Celsius or higher). Chemical interventions include acaricide sprays (Arlian 2001; Friedmann 1999) and antifungal agents that appear to reduce mite numbers because of the apparent symbiotic relationship between mites and fungi (Koren 1993).

Nearly all interventions to reduce or avoid exposure to house dust mite are used in the home. This effort is usually centred around the bedroom of the person affected, as a large percentage of house dust mite exposure is related to close contact with the bed and associated bedding. A regimen with many methods may be used, especially where the house dust mite levels are high or where the person affected experiences severe allergic reactions (Arlian 2001). The significance of any exposure to house dust mites outside the home is not well studied, but is an important consideration, especially as a large proportion of people with eczema will spend many hours each week in another environment, such as school or work.

\section{How the intervention might work}

As many as a third of people with eczema who have a positive test for allergy to house dust mite have reported worsening of eczema or respiratory symptoms when exposed to dust (Hallai 2009). The research into the relationship between house dust mite allergens and eczema has a long history. In 1949, Tuft showed that reducing the levels of house dust mite in the home could benefit people with eczema (Tuft 1949). The exact mechanism by which exposure to house dust mite results in worsening of eczema is unclear; however, 
when people with eczema are patch tested with house dust mite, CD4 positive $\mathrm{T}$ cells specific to house dust mite are found in the patch of skin that has developed eczematous characteristics (Friedmann 1999; van Reijsen 1992).

\section{Why it is important to do this review}

Eczema often follows a chronic, relapsing course (Williams 1994), and people with eczema frequently end up using many different topical and sometimes systemic treatments. Some of these treatments, such as topical corticosteroids, have potentially serious sideeffects (e.g., skin thinning), which although they are rare with appropriate treatment, can lead to low levels of treatment compliance because of an inappropriate level of fear of using the treatment (Charman 2000b).

Many of the interventions that aim to reduce or avoid house dust mite exposure often have few or no known adverse effects. In particular, because of families spending a significant percentage of the total cost of managing eczema on house dust mite control measures (Emerson 2001), it is important that the evidence for these interventions is summarised to highlight any potential benefit or harm. This will enable people with eczema or their caregivers and policy-makers to make more informed decisions.

\section{O B J E C T I V E S}

To assess the effects of all house dust mite reduction and avoidance measures for the treatment of eczema.

\section{METHODS}

\section{Criteria for considering studies for this review}

\section{Types of studies}

Randomised controlled trials (RCTs) that assess the efficacy of any of the house dust mite reduction and avoidance measures for the treatment of eczema. We included trials that allowed cotreatments. We excluded quasi-randomised trials. We would have included cross-over trials, only if the data at the end of the first period were available, because of the possibility of treatment carryover effects, but we did not identify any for inclusion. We would have included cluster-randomised trials but identified none for inclusion.

We excluded trials on house dust mite reduction and avoidance measures for the prevention of eczema.

\section{Types of participants}

Anyone of any age diagnosed with eczema as defined by the World Allergy Organization, or atopic eczema, childhood eczema, or atopic dermatitis by a clinician. We would have included a diagnosis of Besnier's prurigo or neurodermatitis if there was evidence of eczema in the flexures before inclusion, but we identified none for inclusion. We excluded participants with skin comorbidities, such as psoriasis, ichthyosis vulgaris, or skin infections, including infected eczema. We accepted diagnosis using the Hanifin and Rajka criteria (Hanifin 1980) or the UK diagnostic criteria (Williams 1994).

\section{Types of interventions}

All non-pharmacological and pharmacological interventions that seek to reduce or avoid exposure to house dust mite and their faeces (which are also allergenic). The comparators were any active treatment, no treatment, placebo, or standard care only. They are broadly divided into the following categories.

\section{Educational}

- Information on ways to reduce and avoid house dust mite

\section{Environmental manipulation}

- Mattress encasings

- Duvet and pillow encasings

- Removal of soft floor covering (e.g., carpets, rugs)

- Vacuuming (e.g., different number of times, higher filtration)

- Ventilation systems

- Removing people with eczema from their environment for a defined period (e.g., removing children from a school in a lower altitude to a school in a high altitude area)

- Ultraviolet C (UVC) light sources

\section{Pharmacological}

- Acaricide sprays

\section{Types of outcome measures}

\section{Primary outcomes}

1. Clinician-assessed global eczema severity using a named scale (e.g., SCORing Atopic Dermatitis (SCORAD)) or modification of such a scale.

2. Participant- or caregiver-assessed eczema-related quality of life using a named instrument. 


\section{Secondary outcomes}

1. Participant- or caregiver-assessed global eczema severity score.

2. Amount and frequency of topical treatment required.

3. Sensitivity to house dust mite allergen using a marker (e.g., specific IgE).

4. Adverse effects.

\section{Main outcomes for 'Summary of findings' table}

We have provided data in the 'Summary of findings' table for the primary outcome Clinician-assessed global eczema severity using a named scale (e.g., SCORAD) or modification of such a scale. We decided that attempting to include only those severity measurements that were validated was too restrictive and that acceptable validation was difficult to quantify.

\section{Timing of outcome assessment}

Short-term outcomes were six months or less, and long-term outcomes were over six months. Long-term outcomes were of primary importance because of the need to assess whether the treatment effects were sustained over a useful length of time for people with eczema.

\section{Adverse outcomes}

We reported all adverse events from the included and excluded studies and the separate search for rare but potentially serious sideeffects.

\section{Economic data}

We did not consider economic factors in this review.

\section{Search methods for identification of studies}

We aimed to identify all relevant RCTs regardless of language or publication status (published, unpublished, in press, or in progress).

\section{Electronic searches}

We searched the following databases up to 14 August 2014:

- the Cochrane Skin Group Specialised Register using the following search terms: ((atopic and dermatitis) or (atopic and eczema*) or eczema* or neurodermatitis or (infant* and eczema*) or (child* and eczema*) or (besnier* and prurigo)) AND ((house and dust and mite*) or (dust and mite*) or (pyroglyphidae or dermatophagoide* or euroglyphus or blomia));
- the Cochrane Central Register of Controlled Trials (CENTRAL) (2014, Issue 1), in The Cochrane Library using the search strategy in Appendix 1;

- MEDLINE via Ovid (from 1946) using the strategy in Appendix 2;

- Embase via Ovid (from 1974) using the strategy in Appendix 3; and

- LILACS (Latin American \& Caribbean Health Sciences Literature, from 1982) using the strategy in Appendix 4; and

- The Global Resource of EczemA Trials (GREAT database). Centre of Evidence Based Dermatology. Accessed at www.greatdatabase.org.uk on 2 September 2014 using the search strategy 'house' OR 'dust' OR 'mite' across all fields.

\section{Trials databases}

We searched the following trials registers up to 2 September 2014 using the terms 'eczema' and 'house dust mite':

- The metaRegister of Controlled Trials (www.controlledtrials.com).

- The US National Institutes of Health Ongoing Trials Register (www.clinicaltrials.gov).

- The Australian New Zealand Clinical Trials Registry ( www.anzctr.org.au).

- The World Health Organization International Clinical Trials Registry platform (www.who.int/trialsearch).

- The Ongoing Skin Trials Register (www.nottingham.ac.uk/ ongoingskintrials).

\section{Searching other resources}

\section{References from published studies}

We checked the bibliographies of included and excluded studies for further references to relevant RCTs.

\section{Unpublished literature}

We planned to obtain unpublished ongoing trials information via correspondence with trial authors.

\section{Conference proceedings}

We scanned for further RCTs the abstracts from the International Research Workshops on eczema and major dermatology and allergy conference proceedings not already recorded in the Cochrane Skin Group Specialised Register. 


\section{Adverse effects}

We did not perform a separate search for adverse effects of the target interventions. We did examine data on adverse effects of all of the reduction and avoidance measures used for the treatment of eczema from the included studies.

\section{Data collection and analysis}

\section{Selection of studies}

Two authors (HN and EP) independently checked the titles and abstracts identified from the searches. We excluded studies where it was clear that they did not refer to a randomised controlled trial on house dust mite avoidance or reduction measures for the treatment of eczema. When it was unclear, then we obtained the full text of the study, which two authors (HN and EP) independently assessed. The authors decided which trials fitted the inclusion criteria. A third author (RB or HW) would have resolved any disagreement by discussion, but there were no disagreements. We recorded the reasons for exclusion in the 'Characteristics of excluded studies' tables.

\section{Data extraction and management}

Two authors (HN and EP) independently extracted data using a specially designed data extraction form and checked and entered the data into RevMan (Review Manager 2014). Data extracted included participant numbers, characteristics, interventions, outcomes, and results. The same two authors resolved discrepancies between them, with discussion with a third author (RB or HW) if necessary. We obtained missing data from trial authors where possible. We were not blinded to the names of trial authors, journals, or institutions.

\section{Assessment of risk of bias in included studies}

The quality assessment included an evaluation of the following components for each included study, since there is some evidence that these are associated with biased estimates of treatment effect (Higgins 2011):

(a) the method of generation of the randomisation sequence;

(b) the method of allocation concealment - we considered it 'adequate' if the assignment could not have been foreseen;

(c) who was blinded or not blinded (participants, clinicians, outcome assessors); and

(d) how many participants were lost to follow up in each arm (split into postrandomisation exclusions and later losses if possible) and whether participants were analysed in the groups to which they were originally randomised (intention-to-treat).

In addition, we assessed the following: (e) degree of certainty that participants had eczema;

(f) baseline comparison for severity of disease;

(g) whether outcomes and any subgroup analyses were clearly defined; and

(h) treatment compliance - whether or not measurements were taken and, if so, whether they were high.

\section{Measures of treatment effect}

We were unable to combine any of our results because of variability in the interventions and paucity of data. If in future updates of this review it is possible to carry out quantitative analyses, we will do the following: For dichotomous outcomes, we will express the results as risk ratios (RR) and $95 \%$ confidence intervals (CI); we will not express these as odds ratios as the event rates are common and we do not wish to overestimate the treatment effect. We will express the continuous outcomes as mean differences (MD) and 95\% CI. For dichotomous outcomes, we will express the results as number needed to treat (NNT) with $95 \%$ confidence intervals and the baseline risk to which it applies.

\section{Unit of analysis issues}

\section{Cross-over trials}

If we had identified cross-over trials, we would have conducted a paired analysis according to the guidance given in the Cochrane Handbook for Systematic reviews of Interventions, chapter 16 (Higgins 2011). We would have analysed these trials separately to the parallel group studies or studies of other designs.

\section{Cluster trials}

If we had identified cluster trials, we would have analysed these appropriately using the interclass correlation coefficient, and we would have synthesised these with the parallel group.

\section{Within-person trials}

If we had identified within-person trials, we would have abstracted the paired analysis results from the original paper and reported these. We would have analysed these separately from the parallel group and cross-over trials.

\section{Multiple treatment group trials}

One included trial, Colloff 1989, had more than one active intervention arm. If we had had sufficient numbers of studies to carry out a meta-analysis, we would have followed the advice in the Cochrane Handbook for Systematic Reviews of Interventions, chapter 16 (Higgins 2011), and considered, for example, whether any of 
the arms could be sensibly combined, or whether we should include only the arms which were compatible with other trials.

\section{Dealing with missing data}

We contacted study authors for clarification of missing data and summary statistics.

\section{Assessment of heterogeneity}

If we had assessed heterogeneity, we would have used the $\mathrm{I}^{2}$ statistic. If substantial ( $\mathrm{I}^{2}$ statistic > 50\%) heterogeneity had existed between trials for any of the outcomes, we would have explored the reasons for the heterogeneity, such as differences in participant factors or treatment factors. We described the findings narratively, as it was not possible to perform a meta-analysis.

\section{Assessment of reporting biases}

If we could have pooled together 10 or more studies, we would have performed funnel plots to assess possible reporting biases.

\section{Data synthesis}

If trials with similar types of intervention had been available, we would have used a fixed-effect model in the first instance and tested for heterogeneity. We would then have used a random-effects model for further analyses if we had found significant heterogeneity.

\section{Subgroup analysis and investigation of heterogeneity}

If the number of studies allowed, we would have explored the effect of potential confounding variables and effect modifiers of the meta-risk estimate using meta-regression methods, including, for example, severity of eczema, age, length of intervention, sensitivity to house dust mite allergens, and house dust mite allergen levels if the appropriate data had been available.

\section{Sensitivity analysis}

We had planned to explore reasons for heterogeneity between trials and, if necessary, perform sensitivity analyses examining the effects of excluding subgroups, such as very low- or low-quality (GRADE) trials.

\section{RES U L T S}

\section{Description of studies}

\section{Results of the search}

The searches of the Cochrane Skin Group Specialised Register, CENTRAL in The Cochrane Library, MEDLINE, Embase, LILACS, and GREAT databases retrieved 308 unique records. We identified one record through searching other sources, making 309 records in total. Of these 309 records, we excluded 290 after scrutinising the titles and abstracts. We obtained the full texts of the remaining 19 records. From these 19 records, we excluded eight references. The remaining 11 references referred to seven different studies, which we included (see Figure 3). We did not identify any studies that needed further information regarding classification or any ongoing studies. 
Figure 3. Study flow diagram

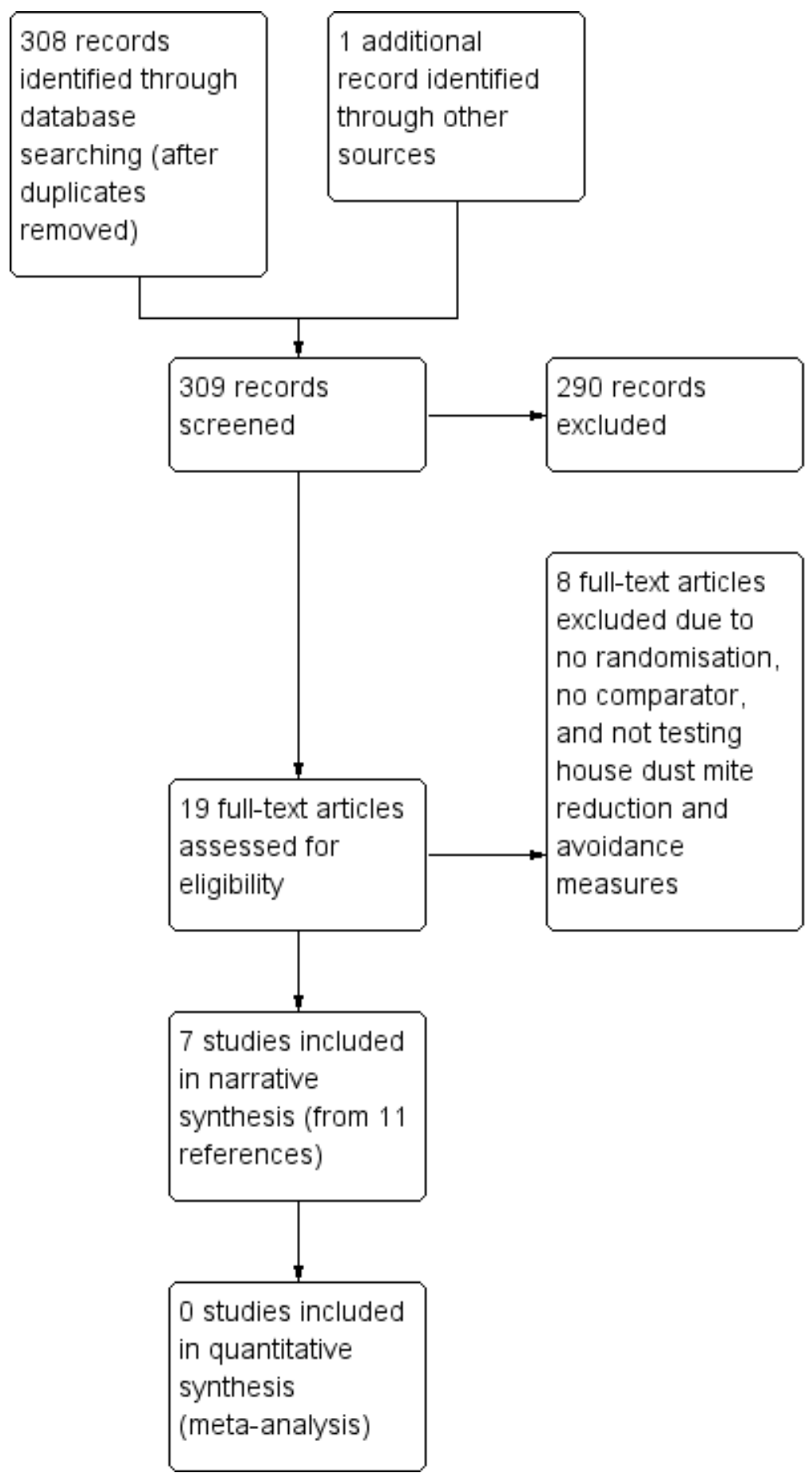




\section{Included studies}

In this review, we included seven studies of 324 adult and child participants with eczema. Eleven references reported these seven studies.

\section{Design}

Six out of the seven included studies divided the participants into two separate groups and performed what was either reported to be or appeared to be from the description a parallel group study (Endo 1997; Gutgesell 2001; Oosting 2002; Ricci 2000; Tan 1996; Terreehorst 2005). The remaining study (Colloff 1989) randomised the participants into four groups.

We did not identify any cross-over trials, cluster trials, or withinperson trials.

\section{Sample sizes}

All seven included studies were small (Colloff 1989; Endo 1997; Gutgesell 2001; Oosting 2002; Ricci 2000; Tan 1996; Terreehorst 2005), ranging from 20 to 86 participants per study. Colloff 1989 randomised 23 participants into four groups, resulting in only four to six participants per group. Eczema is a relatively common condition, especially in childhood, so it is surprising not to have found a larger study on house dust mite reduction and avoidance measures for the treatment of eczema.

\section{Setting}

Details about the setting for the use of the interventions in the studies was very clear and was the same for all seven: The study interventions were all used in the participant's own homes.

Five out of the seven studies reported details of the setting of recruitment and the location of follow-up assessments (Colloff 1989; Endo 1997; Oosting 2002; Tan 1996; Terreehorst 2005). Four studies recruited from secondary care, and one study recruited from both the community (primary care), using an article in the press, and secondary care (Oosting 2002).

\section{Participants}

All of the seven studies gave details about the age of the included participants, which ranged from two to 65 years old. Two of the studies were on children from three to 12 years old and two to 10 years old (Endo 1997; Ricci 2000, respectively); one study, Gutgesell 2001, looked at adults aged 18 to 30 years old; and four studies looked at children and adults aged seven to 65 years old (Tan 1996), eight to 50 years old (Oosting 2002; Terreehorst 2005), and 12 to 47 years old (Colloff 1989). All of the seven studies stated that the participants must have atopic eczema, but only five studies reported the method of diagnosis (Colloff 1989; Endo 1997; Oosting 2002; Ricci 2000; Terreehorst 2005); three of these trials required the participants to fulfil the criteria of Hanifin and Rajka.

\section{Outcomes}

Six of the seven included studies reported outcomes that measured the severity of eczema (Colloff 1989; Endo 1997; Gutgesell 2001; Oosting 2002; Ricci 2000; Tan 1996), but only four of them used a named severity scale (SCORAD; Six Area, Six Sign Atopic Dermatitis (SASSAD); or the Leicester Sign Score (LSS)) (Gutgesell 2001; Oosting 2002; Ricci 2000; Tan 1996). Only one study (Terreehorst 2005) measured quality of life; however, as this study used the SF-36 form (which measures generic quality of life), we could not analyse the data for this review. Four studies out of the seven measured specific serum IgE to house dust mite (Colloff 1989; Endo 1997; Gutgesell 2001; Oosting 2002). One study, Gutgesell 2001, recorded both the amount of topical corticosteroids used and participant-rated global eczema severity.

\section{Interventions}

Of the seven included studies, four looked at complex house dust mite reduction and avoidance interventions (Colloff 1989; Gutgesell 2001; Ricci 2000; Tan 1996), with most interventions aiming to reduce the numbers of house dust mites. Two studies studied bedding encasings only (Oosting 2002; Terreehorst 2005), and one study, Endo 1997, compared different levels of vacuum suction power as the only variable. In total, five of the seven studies included bedding or mattress encasings as part of a complex intervention or on their own (Gutgesell 2001; Oosting 2002; Ricci 2000; Tan 1996; Terreehorst 2005). Four studies included vacuuming (Colloff 1989; Endo 1997; Ricci 2000; Tan 1996). Three studies looked at the use of mite-killing (acaricide) sprays, one containing natamycin (Colloff 1989) and the other two containing tannic acid and benzyl benzoate (Gutgesell 2001; Tan 1996). One study (Ricci 2000) compared a strict routine of dust reduction and avoidance measures, which comprised the use of mattress and pillow encasings, vacuuming of the bedroom and living room carpets twice a week, other carpets vacuumed once a week or removed, removal or washing of soft toys once a week, and hot washing of bedding once a week compared with normal cleaning habits. Another study, Endo 1997, used some standardised house dust mite reduction measures for both groups.

\section{Excluded studies}


We excluded 290 studies from the review by screening the title or abstract. Most of these assessed house dust mite reduction and avoidance measures but did not involve people with eczema. Of the 19 full papers that we obtained and scrutinised, we excluded eight. The reasons for exclusion were as follows: no randomisation, no comparative intervention, and not testing house dust mite reduction and avoidance measures (see the 'Characteristics of excluded studies' tables).

We eventually excluded Holm 2001 because although the study fitted all the review inclusion criteria, it did not mention whether it had randomised the participants. Contact from the authors confirmed that they had not randomised participants to treatment (Acknowledgements). Therefore, we excluded the study.

\section{Risk of bias in included studies}

Please see Figure 4 for the 'Risk of bias' summary. This gives our judgements about each 'Risk of bias' item for each included study. Overall, the included studies have a high risk of bias. 
Figure 4. 'Risk of bias' summary: review authors' judgements about each 'Risk of bias' item for each included study

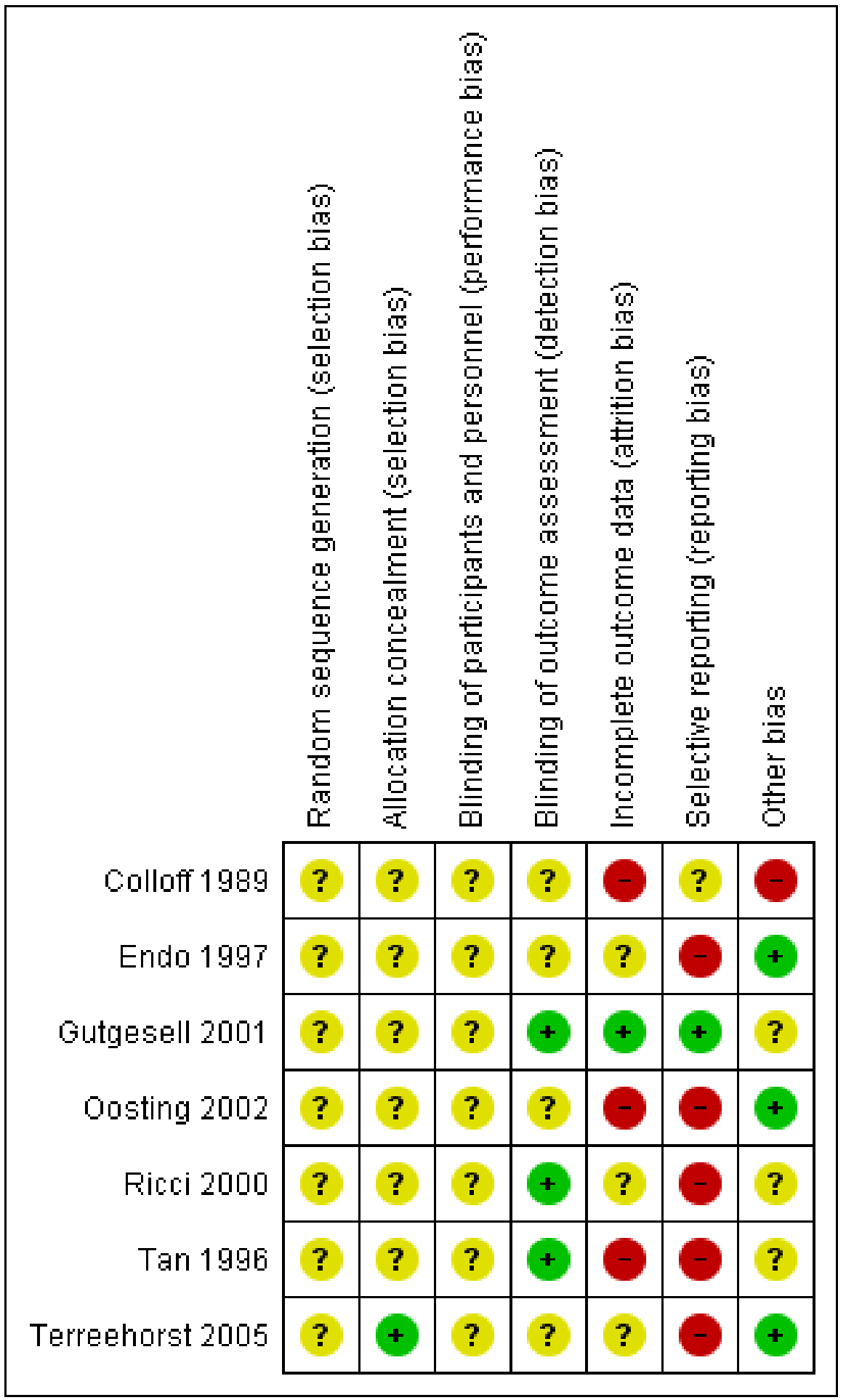




\section{Allocation}

None of the seven included studies provided details about the method of generating the allocation sequence.

Only one of the seven studies, Terreehorst 2005, gave any information at all about the concealment allocation sequence. This study described a process of remote randomisation and dispensing of the intervention to the participants, which makes it highly unlikely that any of the study personnel or participants could have known or predicted the allocation sequence. With so little information about the concealment of allocation to treatment for the other six studies, the risk of selection bias was judged unclear for this domain.

\section{Blinding}

All seven included studies reported that blinding took place; however, information about the methods of blinding and who were blinded are all missing or so brief that it was impossible to make a judgement on the potential for performance bias. Considering that the participants of the studies nearly always had to perform the intervention themselves or have encasings on their bed, it would seem highly unlikely that they were truly blinded in any of the included studies, even if this had been attempted. Only three studies reported that they blinded the person who assessed the eczema severity outcome to the treatment allocation and therefore had a lower risk of detection bias (Gutgesell 2001; Ricci 2000; Tan 1996).

\section{Incomplete outcome data}

None of the included studies reported using intention-to-treat principles for the analysis, and four studies reported a lower number of participants analysed compared with the number of participants randomised (Colloff 1989; Endo 1997; Oosting 2002; Tan 1996). Of particular concern was the difference in the number of withdrawals between the intervention groups in one study (Tan 1996), where $2 / 30$ withdrew from the active intervention group using mite impermeable encasings, acaricide spray, and high-filtration vacuuming compared with $10 / 30$ for the comparative intervention of cotton encasings, placebo spray, and low-filtration vacuuming. Only those that completed this study were analysed.

\section{Selective reporting}

Most of the trials had a high risk of bias for selective reporting, such as outcomes not being compared between groups, subgroup results being given inappropriate prominence, or stated outcomes not being reported in the results.

\section{Other potential sources of bias}

We attempted to contact authors of all the included studies, but were only successful in obtaining additional information for Terreehorst 2005 and Tan 1996.

The data on many of the participants in Terreehorst 2005 had previously been published in 2003, which we listed as a secondary reference to this included study. This previous trial report had stated that all participants were encouraged to hot wash the bedding weekly, which could have masked any beneficial effects of the encasings.

We were able to find additional information about Oosting 2002 in a letter to the editor and a subsequent reply in 2003, which we listed as secondary references to this included study.

In the trial by Colloff 1989, the definition of eczema' classic clinical features and chronic relapsing course of atopic dermatitis' was very wide, raising the possibility that not all participants had eczema. Endo 1997 diagnosed atopic eczema according to the criteria of Hanifin and Rajka, and baseline severity of eczema was comparable between groups. Gutgesell 2001 did not report any details of the definition of eczema. Ricci 2000 described the inclusion criterion as 'the extrinsic variant of $\mathrm{AD}$, i.e. raised serum total $\mathrm{IgE}$ antibodies and/or the presence of specific IgE antibodies to foods or inhalant allergens'. Tan 1996 did not state the method of diagnosis of eczema. It was also stated that there were more participants with severe eczema in one group than the other. Terreehorst 2005 and Oosting 2002 defined eczema according to the Hanifin and Rajka criteria.

\section{Effects of interventions}

\section{See: Summary of findings for the main comparison}

As many of the included studies looked at differing complex interventions, we discuss the results of all the seven included studies narratively. As none of the studies looked at the same outcomes for the same or similar interventions, it was not possible to combine studies in a meta-analysis. Four included studies assessed our primary outcome, 'Clinician-assessed global eczema severity using a named scale (e.g., SCORing Atopic Dermatitis (SCORAD)) or modification of such a scale', and one included study assessed our primary outcome of 'Participant- or caregiver-assessed eczema-related quality of life using a named instrument'.

One included study assessed our secondary outcome of 'Participant- or caregiver-assessed global eczema severity score'. One included study assessed our secondary outcome of 'Amount and frequency of topical treatment required'. Four included studies assessed our secondary outcome of 'Sensitivity to house dust mite allergen using a marker (e.g., specific IgE)'. We did not find any adverse events associated with house dust mite reduction and avoidance methods in the included studies, so we could not address our

House dust mite reduction and avoidance measures for treating eczema (Review) 
secondary outcome of 'Adverse effects'.

\section{Primary outcomes}

\section{Clinician-assessed global eczema severity using a named scale (e.g., SCORing Atopic Dermatitis (SCORAD)) or modification of such a scale}

Two studies measured the severity of eczema using SCORAD. Gutgesell 2001 found no statistically significant difference in reduction of severity after one year $(\mathrm{P}=0.901)$ (non-parametric tests for tests of repeated measures) between the use of allergen impermeable polyurethane encasings and acaricide spray consisting of tannic acid and benzyl benzoate versus allergen permeable cotton encasings and placebo acaricide spray consisting of water and a trace of ethanol. The active encasings group had a reduction in SCORAD from a median (interquartile range) of 46 (37 to 55) to 40 (32 to 63), and the control encasings had a change in SCORAD from 35 ( 24 to 46 ) to 37 (30 to 45 ). This study did not provide many details; we abstracted the SCORAD scores from a graph, and the trial only had 20 participants in total.

The second study by Ricci and colleagues, involving 41 participants (Ricci 2000), only used comparative groups for two months. The study recorded reduction in severity within the group using the dust mite avoidance measures (a reduction from a mean of 33 to 26 SCORAD points) and also the group who used normal cleaning patterns (a reduction from a mean of 27 to 24 SCORAD points). However, despite measuring the reduction in severity, there was no comparison between the two groups.

The paper by Friedmann and colleagues, which was an additional report of the included study by Tan and colleagues involving 60 participants (Tan 1996), reported eczema severity over six months measured using the Six Area, Six Sign Atopic Dermatitis (SASSAD) severity scale, which runs from 0 to 108 . A significant benefit for a complex intervention of a GORE-TEX® bedding system combined with benzyltannate spray and high-filtration vacuuming was reported. The mean difference in the mean severity scores were -12.6 in the active treatment group and -4.2 in the control group. The analysis of the differences in the reduction in severity scores between groups used analysis of covariance with initial eczema scores and logs of the initial mattress dust weight and bedroom carpet Dermatophagoides pteronyssinus (Der) p1 concentration as covariates and reported a mean difference of 4.2 (95\% confidence interval $(\mathrm{Cl}) 1.7$ to 6.7$), \mathrm{P}=0.008$ (unpaired student's t-test), in favour of the GORE-TEX® bedding system, benzyltannate spray, and high-filtration vacuuming.

The trial by Oosting and colleagues, involving 86 participants (Oosting 2002), measured eczema severity using the Leicester Sign Score (LSS) (median and range) over one year and found significant reductions in severity, extent, and itching scales of the LSS within the active treatment group (LSS disease activity 17 (6 to
60 ) to 13 (0 to 55 ), $\mathrm{P}=0.017$ ) (LSS extent 19.5 (3 to 88 ) to 14.5 (0 to 87 ), $\mathrm{P}=0.038$ ) (LSS itching score $\mathrm{mm} 73.5$ (0 to 100) to 63 (4 to 100$), P=0.045$ ), but did not report the total LSS scores. The trial report mentions that there were no significant betweengroup differences, but does not report any more detail.

\section{Participant- or caregiver-assessed eczema-related quality of life using a named instrument}

Only one study, involving 64 participants (Terreehorst 2005), measured quality of life. As a generic self assessment of physical and emotional health scale, SF-36 was used, which does not specifically ask about eczema-related quality of life; it was not directly relevant to this review. No significant differences were found between using mite impermeable encasings or permeable encasings.

\section{Secondary outcomes}

\section{Participant- or caregiver-assessed global eczema severity score}

One study, Gutgesell 2001, recorded participant-assessed skin status using a visual analogue scale. The study found no significant statistical difference between allergen impermeable encasings and acaricide spray consisting of tannic acid and benzyl benzoate compared with allergen permeable cotton encasings and placebo acaricide spray of water with a trace of ethanol. There were only 20 participants. There were no detailed data for this outcome, and there is not enough information to be sure if the participants were blinded in the report.

\section{Amount and frequency of topical treatment required}

Again, only one study, Gutgesell 2001, recorded the amount of topical corticosteroid used. This was recorded by weighing the amount of cream or ointment left in the participant's steroid containers at the end of the study. No significant difference was found between the amount of topical corticosteroid used in each group $(\mathrm{P}=0.624)$ (exact Wilcoxon test), but the study did not report detailed data.

\section{Sensitivity to house dust mite allergen using a validated marker (e.g., specific IgE)}

Four of the seven studies assessed sensitivity to house dust mite using different methods (Colloff 1989; Endo 1997; Gutgesell 2001; Oosting 2002).

One study, involving 23 participants (Colloff 1989), did not analyse between-group differences. Within-group analyses showed statistically significant reductions in serum house dust mite (Dermatophagoides pteronyssinus (D. pteronyssinus))-specific IgE for vacuuming in combination with natamycin treatment $(\mathrm{P}<0.05)$. Vac- 
uuming in combination with placebo treatment also provided significant reductions in serum total $\operatorname{IgE}(\mathrm{P}<0.05)$ and serum house dust mite (D. pteronyssinus)-specific immunoglobulin $\mathrm{G}(\mathrm{IgG})(\mathrm{P}$ $<0.01)$ after 12 weeks. Analysis of the treatment effects were carried out using t-tests.

One study, involving 30 participants (Endo 1997), did not find any significant differences (no between-group statistical tests reported) between the intervention groups, which compared full power vacuuming against half power vacuuming for both total and house dust mite (D. pteronyssinus and Dermatophagoides farina)specific IgE levels after one year.

Oosting 2002, which included 86 participants, did not show any significant difference between the intervention groups for house dust mite-specific IgE levels after one year $(-2.15,-58.5$ to 44.6 for placebo compared with $-2.15,-30.2$ to 33.9$)$. No statistical comparison between the groups was reported, but the difference was described as not significant. The final study, involving 20 participants (Gutgesell 2001), also did not find any significant difference in the house dust mite-specific IgE levels (statistical data were not reported) between the intervention groups after one year.

\section{Adverse effects}

None of the seven included studies reported recording adverse events. We managed to contact one author, who confirmed that no adverse events related to the use of encasings had occurred.

\section{ISCUSSIO N}

\section{Summary of main results}

The small amount of data on the severity of eczema measured using SCORAD in two studies do not present any evidence for a significant benefit of the use of mite impermeable mattress encasings and acaricide spray over placebo (mite permeable encasings) and house dust mite reduction-cleaning practices compared with normal cleaning patterns. One study, involving 60 participants (Tan 1996), which measured the change in eczema severity using SASSAD over six months, found a modest but statistically significant benefit of a GORE-TEX® bedding system combined with benzyltannate spray and high-filtration vacuuming. This study also reported a $98 \%$ reduction in the number of mites in the active treatment group.

None of the included studies reported investigator-assessed global measures of eczema severity. There were little data on participantassessed eczema severity, with one small study of 20 participants, Gutgesell 2001, finding no significant difference between allergen impermeable encasings and acaricide spray versus placebo (cotton encasings and water spray with a trace of ethanol) after two months.
There is no evidence of benefit through reduction in sensitivity to house dust mite, with four studies (159 participants) finding no significant difference in the level of sensitisation to house dust mite between treatment groups. Two out of four trials did not statistically compare the results between treatment groups for this outcome.

None of the included studies looked at eczema-related quality of life.

\section{Overall completeness and applicability of evidence}

All the included studies found for this review are lacking some information about trial methodology and detailed data for some of the reported outcomes, especially numbers of participants included in the analyses. Several did not compare the outcome data between the two treatment groups, leaving readers guessing as to the clinical meaning of the results. The relevance of the change in level of house dust mite sensitivity levels in individuals compared with clinical benefits is obscure.

\section{Quality of the evidence}

Nearly all of the included studies were for an unacceptably short period of time for a long-term chronic condition like eczema. However, as they were mostly investigating interventions with previous evidence of benefit in eczema, it is likely that only shortterm studies would have received ethical approval. There is mostly not enough detail about the interventions carried out to reproduce them, and for most of the trials, there was not enough information about the study population, especially in terms of the details of the eczema diagnosis and severity. Collectively, these factors mean that the evidence is of very low quality. Although the small studies in this review do not seem to provide much evidence to suggest that house dust mite reduction has any beneficial effect on eczema or atopic eczema, they also do not provide much evidence of no benefit. There have not yet been any studies that are both methodologically robust and long enough to be reasonably sure of seeing any beneficial effects, which may be slow to develop.

\section{Potential biases in the review process}

We have taken care to try and eliminate bias from this review; however, it is always possible, although unlikely, that one or more trials have been missed, buried in journals not covered by the review search or buried in a journal's correspondence section. With such little data in the review at present, any missing trials have a greater potential to change the review conclusions. 


\section{Agreements and disagreements with other studies or reviews}

Three clinical guidelines and two systematic reviews have looked at whether house dust mite reduction and avoidance measures are effective for the treatment of eczema (AAD 2003; Hoare 2000; Langan 2006; NICE 2007; SIGN 2011). A review of the potential 'flare factors' for eczema, Langan 2006, briefly summarised the RCTs that have assessed the efficacy of house dust mite reduction and avoidance measures. This review concluded that there was not enough high-quality evidence to determine whether house dust mite reduction and avoidance measures are effective. The NICE guidelines concluded that there was some evidence of benefit from house dust mite reduction measures in adults and children after two to six months of treatment (NICE 2007), although it does point out that there is still room to ask about both the effectiveness and cost-effectiveness of such intensive interventions given the potential degree of clinical improvement. The American Academy of Dermatology (AAD) technical report summarised trials of house dust mite reduction (AAD 2003), and AAD guidelines based on the technical report (Hanifin 2004) stated that there was not enough evidence to make recommendations about avoidance of house dust mite. The systematic review by Hoare and colleagues reported that the small, poorly reported trials found did not provide any convincing evidence about reduction of house dust mite measures and recommended pragmatic single intervention trials for future research (Hoare 2000).

\section{AUTHORS' CONCLUSIONS}

\section{Implications for practice}

There can be little confidence in the observed beneficial effect on severity of eczema (measured using SASSAD) in one small, very low-quality (GRADE approach) trial. As this treatment response has only been seen in those with atopic eczema, with specific sensitivity to one or more aeroallergens, its use in the eczema population as a whole is unknown. This trial also reported a high reduction in the level of mites in the treatment group, which agrees with suggestions from trials in allergic rhinitis (Nurmatov 2012): that it is only a very significant eradication of house dust mites that produces a clinically significant effect for eczema. The potential benefit from a small magnitude of effect needs to be weighed against the impact of sustaining the intervention regimen over long periods of time.

As none of the trials included in this review measured participantor physician-assessed eczema-related quality of life, there is currently no evidence about the impact of house dust mite reduction and avoidance measures on people with eczema.

As many as a third of people with eczema who have a positive test for allergy to house dust mite have reported worsening of eczema or respiratory symptoms when exposed to dust. Four trials, three of which had atopic participants and a fourth that did not require sensitivity to allergens as an inclusion criterion, did not find any evidence of a reduction in the specific sensitivity to house dust mites over one year. This evidence hints that a 'home only' approach to dust mite eradication or reduction is ineffective with regard to the reduction of sensitivity to house dust mite in the eczema population. It is also not clear whether this reduction in a positive reaction to a skin prick test is a poor predictor of a clinically relevant allergy to house dust mite.

Many of the included trials used multiple different interventions simultaneously; however, the separate tasks themselves were not particularly onerous. It is plausible that families would be willing to use these interventions to see improvements in eczema. Where the interventions are particularly complex or intensive for parents and carers, there is potential for difficulties, such as lack of compliance and pressure on time, finances, and emotional energy.

The evidence available for house dust mite reduction and avoidance measures falls far short of a basis for influencing clinical practice.

\section{Implications for research}

No significant clinical benefit of any house dust mite reduction or avoidance interventions lasting long enough to be satisfactory to those with a long-term chronic condition such as eczema has yet been shown. The included studies have so far lacked methodological clarity, which leads to a lack of certainty about the modest positive results shown. Any future trials on reduction of house dust mite need to address the impact on eczema-related quality of life. Future trials on reduction or avoidance of house dust mite for treating eczema are worth pursuing. Such trials should test a clearly reported single intervention against an appropriate comparator, such as a standard care package, only in order to be clear about which of the many candidate interventions are worth testing further. The eczema trial populations should be well characterised, and trials should provide at least a year of treatment with additional long-term follow up.

\section{ACKNOWLEDGEMENTS}

This review presents independent research commissioned by the National Institute for Health Research (NIHR) under its Programme Grants for Applied Research funding scheme (RP-PG0407-10177). The views expressed in this review are those of the author(s) and not necessarily those of the NHS, the NIHR or the Department of Health.

The authors wish to thank Annika Scheynius, personal communication 10 January 2013, with regard to the study by Holm 2001; Peter Friedmann, personal communication 23 May 2012, with 
regard to the study by Tan 1996; and Ingrid Terreehorst, personal communication, with regard to her study published in 2005

(Terreehorst 2005).

The Cochrane Skin Group editorial base wishes to thank Michael Bigby, who was the Cochrane Dermatology Editor for this review; Jo Leonardi-Bee, who was the Statistical Editor; Philippa Middleton, who was Methods Editor; the clinical referees, Peter Lio and Eric Simpson; and the consumer referee, Anjna Rani.

\section{CRG Funding Acknowledgement}

The National Institute for Health Research (NIHR) is the largest single funder of the Cochrane Skin Group.

\section{R E F E R E N C E S}

\section{References to studies included in this review}

\section{Colloff 1989 \{published data only\}}

Colloff MJ, Lever RS, McSharry CM. A controlled trial of house dust mite eradication using natamycin in homes of patients with atopic dermatitis: effect on clinical status and mite populations. British Journal of Dermatology 1989;121 (2):199-208. [MEDLINE: 2673323]

Endo 1997 \{published data only\}

Endo K, Fukuzumi T, Adachi J, Kojima M, Aoki T, Yoshida $\mathrm{M}$, et al.Effect of vacuum cleaning of room floors and bed clothes of patients on house dust mite counts and clinical scores of atopic dermatitis. A double blind control trial (Japanese). Arerugi - Japanese Journal of Allergology 1997;46 (10):1013-24. [MEDLINE: 9404089]

Gutgesell 2001 \{published data only\}

Gutgesell C, Heise S, Seubert S, Seubert A, Domhof $S$, Brunner E, et al.Double-blind placebo-controlled house dust mite control measures in adult patients with dermatitis. British Journal of Dermatology 2001;145(1): 70-4. [MEDLINE: 11453909]

\section{Oosting 2002 \{published data only\}}

Gutgesell C. Atopic dermatitis and the clinical effect of house dust mite avoidance. Journal of Allergy \& Clinical Immunology 2003;111(1):203-4. [MEDLINE: 12532125] Oosting AJ, de Bruin-Weller MS, Bruijnzeel-Koomen CAFM. Author reply. Journal of Allergy \& Clinical Immunology 2003;111(1):203-4.

* Oosting AJ, de Bruin-Weller MS, Terreehorst I, TempelsPavlica Z, Aalberse RC, de Monchy JG, et al.Effect of mattress encasings on atopic dermatitis outcome measures in a double-blind, placebo-controlled study: the Dutch mite avoidance study. Journal of Allergy \& Clinical Immunology 2002;110(3):500-6. [MEDLINE: 12209102]

Ricci 2000 \{published data only\}

* Ricci G, Patrizi A, Specchia F, Menna L, Bottau P, D'Angelo V, et al.Effect of house dust mite avoidance measures in children with atopic dermatitis. British Journal of Dermatology 2000;143(2):379-84. [MEDLINE: 10951149]

Ricci G, Patrizi A, Specchia F, Menna L, Bottau P, D’Angelo $\mathrm{V}$, et al.Mite allergen (Der p1) levels in houses of children with atopic dermatitis: the relationship with allergometric tests. British Journal of Dermatology 1999;140(4):651-5. [MEDLINE: 10233315]

Tan 1996 \{published data only\}

Friedmann PS, Tan BB. Mite elimination - clinical effect on eczema. Allergy 1998;53(Suppl 48):97-100. [MEDLINE: 10096818]

* Tan BB, Weald D, Strickland I, Friedmann PS. Doubleblind controlled trial of effect of housedust-mite allergen avoidance on atopic dermatitis. Lancet 1996;347(8993): 15-8. [MEDLINE: 8531541]

Terreehorst 2005 \{published data only\}

* Terreehorst I, Duivenvoorden HJ, Tempels-Pavlica Z, Oosting AJ, de Monchy JG, Bruijnzeel-Koomen CA, et al.The effect of encasings on quality of life in adult house dust mite allergic patients with rhinitis, asthma and/or atopic dermatitis. Allergy 2005;60(7):888-93. [MEDLINE: 15932378]

Terreehorst I, Hak E, Oosting AJ, Tempels-Pavlica Z, de Monchy JG, Bruijnzeel-Koomen CA, et al.Evaluation if impermeable covers for bedding in patients with allergic rhinitis. New England Journal of Medicine 2003;349(3): 237-46. [MEDLINE: 12867607]

\section{References to studies excluded from this review}

Adham 2011 \{published data only\} Adham TM, Tawfik SA, Abdo NM. House dust mites in pediatric atopic dermatitis. Saudi Medical Journal 2011;37 (2):177-82. [MEDLINE: 21301766]

Corver 2006 \{published data only\} Corver K, Kerkhof M, Brussee JE, Brunekreef B, van Strien $\mathrm{RT}$, Vos AP, et al.House dust mite allergen reduction and 
allergy at 4yr: Follow up of the PIAMA-study. Pediatric Allergy \& Immunology 2006;17(5):329-36. [MEDLINE: 16846450]

D’Souza 1973 \{published data only\} D'Souza MF, Pepys J, Wells ID, Tai E, Palmer F, Overell BG, et al.Hyposensitisation with Dermatophagoides pteronyssinus in house dust allergy: a controlled study of clinical and immunological effects. Clinical Allergy 1973;3 (2):177-93. [MEDLINE: 4131252]

Holm 2001 \{published and unpublished data\}

* Holm L, Bengtsson A, van Hage-Hamsten M, Ohman S, Scheynius A. Effectiveness of occlusive bedding in the treatment of atopic dermatitis - a placebo-controlled trial of 12 months' duration. Allergy 2001;56(2):152-8. [MEDLINE: 11167376]

Kim 2005 \{published data only\}

Kim B, Kim C. Effect of mattress and pillow encasings on children with atopic dermatitis. Journal of Allergy o Clinical Immunology 2005;115(2 Suppl):S101.

Norris 1987 \{published data only\}

Norris PG. Does house dust mite aggravate atopic eczema?. British Journal of Dermatology 1987;117(Suppl 32):14.

Sanda 1992 \{published data only\} Sanda T, Yasue T, Oohashi M, Yasue A. Effectiveness of house dust mite allergen avoidance through clean room therapy in patients with atopic dermatitis. Journal of Allergy \& Clinical Immunology 1992;89(3):653-7. [MEDLINE: 1545086]

Weber-Chrysochoou 2007 \{published data only\} Weber-Chrysochoou C, Crisafulli D, Almqvist C, Li Q, Kemp AS, Britton WJ, et al.IL-5 T-cell responses to house dust mite are associated with the development of allergenspecific $\operatorname{IgE}$ resonses and asthma in the first 5 years of life. Journal of Allergy \& Clinical Immunology 2007;120(2): 286-92. [MEDLINE: 17666216]

\section{Additional references}

\section{AAD 2003}

AAD Expert Work Group. Guidelines for the care of atopic dermatitis: technical report. 2003.

\section{Arlian 2001}

Arilan LG, Platts-Mills TA. The biology of dust mites and the remediation of mite allergens in allergic disease. Journal of Allergy \& Clinical Immunology 2001;107(3 Suppl): S406-13. [MEDLINE: 11242601]

\section{Bath-Hextall 2008}

Bath-Hextall FJ, Delamere FM, Williams HC. Dietary exclusions for established atopic eczema. Cochrane Database of Systematic Reviews 2008, Issue 1. [DOI: 10.1002/ 14651858.CD005203.pub2]

\section{Baum 2002}

Baum WF, Schneyer U, Lantzsch AM, Kloditz E. Delay of growth and development in children with bronchial asthma, atopic dermatitis and allergic rhinitis. Experimental
\& Clinical Endocrinology \& Diabetes 2002;110(2):53-9.

[MEDLINE: 11928066]

\section{Beck 2000}

Beck L, Leung DY. Allergen sensitization through the skin induces systemic allergic responses. Journal of Allergy \& Clinical Immunology 2000;106(5):S258-63. [MEDLINE: 11080741]

\section{Birnie 2008}

Birnie AJ, Bath-Hextall FJ, Ravenscroft JC, Williams HC. Interventions to reduce Staphylococcus aureus in the management of atopic eczema. Cochrane Database of Systematic Reviews 2008, Issue 3. [DOI: 10.1002/ 14651858.CD003871.pub2]

\section{Bjorksten 2001}

Bjorksten B, Sepp E, Julge K, Voor T, Mikelsaar M. Allergy development and the intestinal microflora during the first year of life. Journal of Allergy \& Clinical Immunology 2001; 108(4):516-20. [MEDLINE: 11590374]

Boyle 2008

Boyle RJ, Bath-Hextall FJ, Leonardi-Bee J, Murrell DF, Tang MLK. Probiotics for treating eczema. Cochrane Database of Systematic Reviews 2008, Issue 4. [DOI: 10.1002/14651858.CD006135.pub2]

\section{Brauer 2007}

Brauer M, Hoek G, Smit HA, de Jongste JC, Gerritsen J, Postma DS, et al.Air pollution and development of asthma, allergy and infections in a birth cohort. European Respiratory Journal 2007;29(5):879-88. [MEDLINE: 17251230]

\section{Charman 2000a}

Charman C, Williams H. Outcome measures of disease severity in atopic eczema. Archives of Dermatology 2000;136 (6):763-9. [MEDLINE: 10871941]

\section{Charman 2000b}

Charman CR, Morris AD, Williams HC. Topical corticosteroid phobia in patients with atopic eczema. British Journal of Dermatology 2000;142(5):931-6. [MEDLINE: 10809850]

\section{Curtiss 2007}

Curtiss FR. Atopic march to a dead end or does the theory really have legs?. Journal of Managed Care Pharmacy 2007; Vol. 13, issue 9:810-1. [MEDLINE: 18062733]

\section{Ellis 2002}

Ellis CN, Drake LA, Prendergast MM, Abramovits W, Boguniewicz M, Daniel CR, et al.Cost of atopic dermatitis and eczema in the United States. Journal of the American Academy of Dermatology 2002;46(3):361-70. [MEDLINE: 11862170]

\section{Emerson 1998}

Emerson RM, Williams HC, Allen BR. Severity distribution of atopic dermatitis in the community and its relationship to secondary referral. British Journal of Dermatology 1998; 139(1):73-6. [MEDLINE: 9764151]

\section{Emerson 2001}

Emerson RM, Williams HC, Allen BR. What is the cost of atopic dermatitis in preschool children?. British Journal of Dermatology 2001;144(3):514-22. 


\section{Flohr 2004}

Flohr C, Johansson SG, Wahlgren CF, Williams H. How atopic is atopic dermatitis?. Journal of Allergy \& Clinical Immunology 2004;114(1):150-8. [MEDLINE: 15241359]

Friedmann 1999

Friedmann PS. Dust mite avoidance in atopic dermatitis. Clinical \& Experimental Dermatology 1999;24(6):433-7. [MEDLINE: 10606941]

\section{Gotzsche 2008}

Gotzsche PC, Johansen HK. House dust mite control measures for asthma. Cochrane Database of Systematic Reviews 2008, Issue 2. [DOI: 10.1002/ 14651858.CD001187.pub3]

Hallai 2009

Hallai N, Gawkrodger DJ. Patch testing to aeroallergens, especially house dust mite, is often positive in atopics with eczema of the hands and face. Journal of the European Academy of Dermatology \& Venereology 2009; Vol. 23, issue 6:728-30. [MEDLINE: 19250329]

\section{Hanifin 1980}

Hanifin JM, Rajka G. Diagnostic features of atopic dermatitis. Acta Dermato-Venereologica 1980;60(Suppl 92): 44-7.

\section{Hanifin 2004}

Hanifin JM, Cooper KD, Ho VC, Kang S, Krafchik $\mathrm{BR}$, Margolis DJ, et al.Guidelines of care for atopic dermatitis, developed in accordance with the American Academy of Dermatology (AAD)/American Academy of Dermatology Association "Administrative Regulations for Evidence-Based Clinical Practice Guidelines". Journal of the American Academy of Dermatology 2004;50(3):391-404. [MEDLINE: 14988682]

\section{Higgins 2011}

Higgins JPT, Green S (editors). Cochrane Handbook for Systematic Reviews of Interventions Version 5.1.0 [updated March 2011]. The Cochrane Collaboration, 2011. Available from www.cochrane-handbook.org.

\section{Hoare 2000}

Hoare C, Li Wan Po A, Williams H. Systematic review of treatments for atopic eczema. Health Technology Assessment 2000;4(37):1-191. [MEDLINE: 11134919]

\section{Johansson 2001}

Johansson SG, Hourihane JO, Bousquet J, BruijnzeelKoomen C, Dreborg S, Haahtela T, et al.A revised nomenclature for allergy. An EAACI position statement from the EAACI nomenclature task force. Allergy 2001;56 (9):813-24. [MEDLINE: 11551246]

\section{Johansson 2004}

Johansson SG, Bieber T, Dahl R, Friedmann P, Lanier BQ, Lockey RF, et al.Revised nomenclature for allergy for global use: Report of the Nomenclature Review Committee of the World Allergy Organization, October 2003. Journal of Allergy \& Clinical Immunology 2004;113(5):832-6. [MEDLINE: 15131563]

\section{Kemp 2003}

Kemp AS. Cost of illness of atopic dermatitis in children: a societal perspective. Pharmacoeconomics 2003;21(2): 105-13. [MEDLINE: 12515572]

Koren 1993

Koren LGH. Long term efficacy of acarides against house dust mites (Dermatophagoides pteronyssinus) in a seminatural test system. Proceedings of the First International Conference on Urban Pests. 1993:367-71.

\section{Langan 2006}

Langan SM, Williams HC. What causes worsening of eczema? A systematic review. British Journal of Dermatology 2006;155(3):504-14. [MEDLINE: 16911274]

\section{Mancini 2008}

Mancini AJ, Kaulback K, Chamlin SL. The socioeconomic impact of atopic dermatitis in the United States: A systematic review. Pediatric Dermatology 2008;25(1):1-6. [MEDLINE: 18304144]

\section{McHenry 1995}

McHenry PM, Williams HC, Bingham EA. Management of atopic eczema. Joint Workshop of the British Association of Dermatologists and the Research Unit of the Royal College of Physicians of London. BMJ 1995;310(6983): 843-7. [MEDLINE: 7711624]

\section{Meltzer 2008}

Meltzer LJ, Moore M. Sleep disturbances in parents of children and adolescents with chronic illnesses: prevalence, causes and consequences. Journal of Pediatric Psychology 2008;33(3):279-91. [MEDLINE: 18084038]

\section{Mitchell 1982}

Mitchell EB, Crow J, Chapman MD, Jouhal SS, Pope FM, Platts-Mills TA. Basophils in allergen-induced patch test sites in atopic dermatitis. Lancet 1982;1(8264):127-30. [MEDLINE: 6119511]

\section{Muller 2009}

Muller S, Marenholz I, Lee YA, Sengler C, Zitnik SE, Griffioen RW, et al.Association of Filaggrin loss-of-functionmutations with atopic dermatitis and asthma in the early treatment of the atopic child (ETAC) population. Pediatric Allergy \& Immunology 2009;20(4):358-61. [MEDLINE: 19538357]

\section{NICE 2007}

National Collaborating Centre for Women's and Children's Health (UK). Atopic Eczema in Children: Management of Atopic Eczema in Children from Birth up to the Age of 12 Years. Vol. NICE Clinical Guidelines, No. 57, London: RCOG Press, 2007 Dec. [: www.ncbi.nlm.nih.gov/books/ NBK49365/]

\section{Nurmatov 2012}

Nurmatov U, van Schayck CP, Hurwitz B, Sheikh A. House dust mite avoidance measures for perennial allergic rhinitis: an updated Cochrane systematic review. Allergy 2012;67

(2):158-65. [MEDLINE: 22103686]

\section{Penard -Mornard 2005}

Penard-Morand C, Charpin D, Raherison C, Kopferschmitt C, Caillaud D, Lavaud F, et al.Long-term exposure to 
background air pollution related to respiratory and allergic health in schoolchildren. Clinical \& Experimental Allergy 2005;35(10):1279-87. [MEDLINE: 16238786]

\section{Platts-Mills 1983}

Platts-Mills TA, Mitchell EB, Rowntree S, Chapman MD, Wilkins SR. The role of dust mite allergens in atopic dermatitis. Clinical \& Experimental Dermatology 1983;8 (3):233-47. [MEDLINE: 6883791]

\section{Platts-Mills 2008}

Platts-Mills TA. Allergen avoidance in the treatment of asthma: problems with the meta-analysis. Journal of Allergy \& Clinical Immunology 2008;122(4):694-6. [MEDLINE: 19014759]

\section{Review Manager 2014}

The Nordic Cochrane Centre, The Cochrane Collaboration. Review Manager (RevMan). 5.3. Copenhagen: The Nordic Cochrane Centre, The Cochrane Collaboration, 2014.

\section{SIGN 2011}

Scottish Intercollegiate Guidelines Network (SIGN). Management of atopic eczema in primary care. A national clinical guideline, SIGN publication no. 125, March 2011. http://sign.ac.uk/pdf/sign125.pdf (accessed 14 August 2014).

\section{Su 1997}

Su JC, Kemp AS, Varigos GA, Nolan TM. Atopic eczema: Its impact on the family and financial cost. Archives of Disease in Childhood 1997;76(2):159-62. [MEDLINE: 9068310]

Tuft 1949

Tuft L. Importance of inhalant allergens in atopic dermatitis. Journal of investigative Dermatology 1949;12(4):211-9. [MEDLINE: 18120700]

Van Bever 2002

Van Bever HP. Early events in atopy. European Journal of Pediatrics 2002;161(10):542-6. [MEDLINE: 12297901]

\section{van den Oord 2009}

van den Oord R, Sheikh A. Filaggrin gene defects and risk of developing allergic sensitisation and allergic disorders: Systematic review and meta-analysis. BMJ 2009;339: b2433. [MEDLINE: 19589816]

van Reijsen 1992

van Reijsen FC, Bruijnzeel-Koomen CA, Kaltoff FS, Maggi E, Romagnani S, Westland JK, et al.Skin-derived aeroallergen-specific T-cell clones of Th2 phenotype in patients with atopic dermatitis. Journal of Allergy \& Clinical Immunology 1992;90(2):184-93. [MEDLINE: 1380019]

\section{Verboom 2002}

Verboom P, Hakkaart-Van L, Sturkenboom M, De Zeeuw $\mathrm{R}$, Menke H, Rutten F. The cost of atopic dermatitis in the Netherlands: An international comparison. British Journal of Dermatology 2002;147(4):716-24. [MEDLINE: 12366418]

\section{Williams 1994}

Williams HC, Burney PG, Hay RJ, Archer CB, Shipley MJ, Hunter JJ, et al.The U.K Working Party's diagnostic criteria for atopic dermatitis. British Journal of Dermatology 1994; 131(3):383-96. [MEDLINE: 7918015]

\section{Williams 1999}

Williams HC, Robertson C, Stewart A, Ait-Khaled N, Anabwani G, Anderson R, et al.Worldwide variations in the prevalence of symptoms of atopic eczema in the international study of asthma and allergies in childhood. Journal of Allergy \& Clinical Immunology 1999;103(1 Pt 1): 125-38. [MEDLINE: 9893196]

\section{Williams 2006}

Williams H, Flohr C. How epidemiology has challenged 3 prevailing concepts about atopic dermatitis. Journal of Allergy \& Clinical Immunology 2006;118(1):209-13. [MEDLINE: 16815157]

* Indicates the major publication for the study 


\section{CHARACTERISTICS OF STUDIES}

\section{Characteristics of included studies [ordered by study ID]}

\section{Colloff 1989}

\begin{tabular}{|c|c|}
\hline Methods & Randomised parallel group (4-arm) \\
\hline Participants & $\begin{array}{l}\text { Inclusion criteria } \\
\text { - people with clinical features and chronic, relapsing course of atopic dermatitis } \\
\text { - with a positive immediate skin prick response to house dust mite extract } \\
\text { - confirmed positive by RAST to anti-HDM } \\
\text { - elevated total IgE } \\
\text { The study randomised } 23 \text { participants, but did not report how many were randomised } \\
\text { to each group }\end{array}$ \\
\hline Interventions & $\begin{array}{l}\text { - only in bedrooms, only } 1 \text { pillow per bed - vacuuming of upper surfaces of } \\
\text { mattress and both sides of the pillow just before natamycin spray; natamycin spray } \\
\text { ( } 625 \mathrm{mg} \text { for a single bed, } 1250 \mathrm{mg} \text { for a double bed) on upper surfaces of mattresses } \\
\text { and both sides of the pillow; placebo } \\
\text { - The combinations of interventions in the } 4 \text { arms of the trial were as follows: } \\
\text { natamycin and vacuuming; natamycin and no vacuuming; placebo spray and } \\
\text { vacuuming; placebo spray and no vacuuming } \\
\text { Duration: } 4 \text { months }\end{array}$ \\
\hline Outcomes & $\begin{array}{l}\text { - Eczema severity (scale not named or validated) } \\
\text { - RAST for IgE or IgG to house dust mite (D. pteronyssinus) }\end{array}$ \\
\hline Notes & - \\
\hline
\end{tabular}

Risk of bias

\begin{tabular}{l|l|l}
\hline Bias & Authors' judgement & Support for judgement \\
\hline $\begin{array}{l}\text { Random sequence generation (selection } \\
\text { bias) }\end{array}$ & Unclear risk & $\begin{array}{l}\text { The study gave no details beyond "randomly al- } \\
\text { located" }\end{array}$ \\
\hline $\begin{array}{l}\text { Allocation concealment (selection bias) } \\
\text { Blinding of participants and personnel } \\
\text { (performance bias) } \\
\text { All outcomes }\end{array}$ & Unclear risk & $\begin{array}{l}\text { The study gave no details about whether this was } \\
\text { done }\end{array}$ \\
\hline $\begin{array}{l}\text { Blinding of outcome assessment (detection } \\
\text { bias) } \\
\text { All outcomes }\end{array}$ & Unclear risk & $\begin{array}{l}\text { The study provided no details about the blinding } \\
\text { of participants or personnel }\end{array}$ \\
\hline
\end{tabular}

Incomplete outcome data (attrition bias) High risk All outcomes
The study did not include participants who withdrew in the final analysis. (20/23 participants were 
Colloff 1989 (Continued)

\begin{tabular}{|c|c|c|}
\hline & & $\begin{array}{l}\text { included in the analysis: natamycin and vacu- } \\
\text { uming group = 6; natamycin and no vacuuming } \\
\text { group = 4; placebo spray and vacuuming group = } \\
5 \text {; placebo spray and no vacuuming }=5 \text { ) }\end{array}$ \\
\hline Selective reporting (reporting bias) & Unclear risk & $\begin{array}{l}\text { There were no details of any prespecified out- } \\
\text { comes reported }\end{array}$ \\
\hline Other bias & High risk & $\begin{array}{l}\text { The definition of eczema, 'classic clinical features } \\
\text { and chronic relapsing course of atopic dermatitis', } \\
\text { was very wide, raising the possibility that not all } \\
\text { participants had eczema }\end{array}$ \\
\hline
\end{tabular}

Endo 1997

\begin{tabular}{l|l}
\hline Methods & Randomised, blinded parallel group (2-arm), single-centre \\
\hline Participants & $\begin{array}{l}\text { Inclusion criteria } \\
\text { children with moderate stable atopic eczema based on the Hanafin and Rajka } \\
\text { criteria for more than } 1 \text { month } \\
\text { - a positive (more than class } 2) \text { RAST to house dust mite }\end{array}$ \\
\hline The study randomised 30 participants in total
\end{tabular}

\section{Risk of bias}

\begin{tabular}{l|l|l}
\hline Bias & Authors' judgement & Support for judgement \\
\hline $\begin{array}{l}\text { Random sequence generation (selection } \\
\text { bias) }\end{array}$ & Unclear risk & The study gave no information about this \\
\hline $\begin{array}{l}\text { Allocation concealment (selection bias) } \\
\begin{array}{l}\text { Blinding of participants and personnel } \\
\text { (performance bias) } \\
\text { All outcomes }\end{array}\end{array}$ & Unclear risk & The study gave insufficient details \\
\hline
\end{tabular}


Endo 1997 (Continued)

\begin{tabular}{|c|c|c|}
\hline $\begin{array}{l}\text { Blinding of outcome assessment (detection } \\
\text { bias) } \\
\text { All outcomes }\end{array}$ & Unclear risk & The study gave no details \\
\hline $\begin{array}{l}\text { Incomplete outcome data (attrition bias) } \\
\text { All outcomes }\end{array}$ & Unclear risk & $\begin{array}{l}\text { The study did not include in the analyses } \\
\text { outcome data for } 2 / 30(7 \%) \text { participants } \\
\text { lost to follow up }\end{array}$ \\
\hline Selective reporting (reporting bias) & High risk & $\begin{array}{l}\text { The study did not compare the data from } \\
\text { the groups, only the data within each group }\end{array}$ \\
\hline Other bias & Low risk & $\begin{array}{l}\text { The study diagnosed atopic eczema accord- } \\
\text { ing to the criteria of Hanifin and Rajka; } \\
\text { baseline severity of eczema was comparable }\end{array}$ \\
\hline
\end{tabular}

\section{Gutgesell 2001}

\begin{tabular}{l|l}
\hline Methods & Randomised parallel group (2-arm) \\
\hline Participants & $\begin{array}{c}\text { Inclusion criteria } \\
\text { - aged } 18 \text { to } 30\end{array}$ \\
& $\begin{array}{l}\text { - moderate to severe atopic eczema (method of diagnosis not stated) } \\
\text { - positive RAST class } 3 \text { or above } \\
\text { - specific IgE to Der } p\end{array}$ \\
\hline The study randomised 20 participants in total
\end{tabular}

\section{Risk of bias}

\begin{tabular}{|c|c|c|}
\hline Bias & Authors' judgement & Support for judgement \\
\hline $\begin{array}{l}\text { Random sequence generation (selection } \\
\text { bias) }\end{array}$ & Unclear risk & $\begin{array}{l}\text { The study gave no information about the gener- } \\
\text { ation of the randomisation sequence }\end{array}$ \\
\hline Allocation concealment (selection bias) & Unclear risk & $\begin{array}{l}\text { The study gave no information about conceal- } \\
\text { ment of the allocation sequence }\end{array}$ \\
\hline
\end{tabular}




\section{Gutgesell 2001 (Continued)}

Blinding of participants and personnel Unclear risk (performance bias)

All outcomes

Blinding of outcome assessment (detection Low risk bias)

All outcomes

Incomplete outcome data (attrition bias) Low risk

All outcomes

Selective reporting (reporting bias)

Low risk

Other bias
There were no details about who was blinded, except for the evaluating physician

The evaluating physician was not aware of the allocation of treatment to the participants

Oosting 2002

\begin{tabular}{|c|c|}
\hline Methods & Randomised parallel group (2-arm) \\
\hline Participants & $\begin{array}{l}\text { Inclusion criteria } \\
\text { - atopic eczema diagnosis according to criteria of Hanifin and Rajka } \\
\text { - } 0.7 \text { or above RAST for house dust mite, skin test index, or both } \\
\text { - } 200 \mathrm{ng} \text { per gram or over of dust in the mattress (Der p } 1 \text { or } \operatorname{Der} f 1 \text { ) } \\
\text { The study randomised } 86 \text { participants to treatment }\end{array}$ \\
\hline Interventions & $\begin{array}{l}\text { - GORE-TEX® bedding system (mattress, pillow, and duvet encasings), placebo } \\
\text { (cotton) bedding system (mattress, pillow, and duvet encasings) } \\
\text { - The frequency with which the interventions were performed was not reported } \\
\text { Duration: The interventions were given for } 1 \text { year }\end{array}$ \\
\hline Outcomes & $\begin{array}{l}\text { - Severity of eczema (Leicester Sign Score) } \\
\text { - Participant-assessed itching and sleeplessness (VAS) } \\
\text { - Sensitivity to house dust mite allergen (intradermal test, serum-specific IgE to Der } \\
\text { p1, atopy patch test) } \\
\text { - Total serum IgE } \\
\text { - Total eosinophil count }\end{array}$ \\
\hline
\end{tabular}

Notes

The study measured levels of dust and $\operatorname{Der} p 1$, but they did not appear to be prespecified outcomes

\section{Risk of bias}

\section{Bias}

Random sequence generation (selection Unclear risk bias)
All participants completed the study and were included in the analysis

All planned outcomes had their results reported

The study reported no details of the definition of eczema 


\section{Oosting 2002 (Continued)}

\begin{tabular}{l|l|l}
\hline Allocation concealment (selection bias) & Unclear risk & $\begin{array}{l}\text { The study reported no information about alloca- } \\
\text { tion concealment }\end{array}$ \\
\hline $\begin{array}{l}\text { Blinding of participants and personnel } \\
\text { (performance bias) } \\
\text { All outcomes }\end{array}$ & Unclear risk & $\begin{array}{l}\text { The study gave no information except that the } \\
\text { nurses taking the dust samples were blinded to } \\
\text { treatment allocation. The study stated double- } \\
\text { blind, but did not report details reported }\end{array}$ \\
\hline $\begin{array}{l}\text { Blinding of outcome assessment (detection } \\
\text { bias) } \\
\text { All outcomes }\end{array}$ & Unclear risk & $\begin{array}{l}\text { The study gave no information about blinding } \\
\text { the outcome assessment }\end{array}$ \\
\hline $\begin{array}{l}\text { Incomplete outcome data (attrition bias) } \\
\text { All outcomes }\end{array}$ & High risk & $\begin{array}{l}\text { The numbers for the analysis were lower than the } \\
\text { number of participants randomised (73/86 par- } \\
\text { ticipants) }\end{array}$ \\
\hline Selective reporting (reporting bias) & High risk & $\begin{array}{l}\text { Placebo outcome changes were greater in some } \\
\text { instances, but the trial report did not mention this }\end{array}$ \\
\hline Other bias & Low risk & $\begin{array}{l}\text { Eczema definition was according to the criteria of } \\
\text { Hanifin and Rajka }\end{array}$ \\
\hline
\end{tabular}

Ricci 2000

Methods

Participants

Randomised 2-arm trial (design not clear)

\section{Inclusion criteria}

- aged 2 to 10 years

- diagnosed with atopic eczema according to the Hanifin and Rajka criteria

- all had raised total IgE antibodies to food or inhalant allergens or a positive skin prick test for food or inhalant allergens

The study randomised 41 participants in total
- 1 group $(\mathrm{n}=21)$ were instructed to clean as per the following list: mattress and pillow encasings, hot wash of bedding once a week, living room and bedroom vacuumed at least twice a week, soft toys taken out of the bedroom or washed at least once a week, carpets vacuumed at least once a week/removed, no pets

- Another group $(\mathrm{n}=20)$ were given no specific instructions for 2 months, then they were instructed to follow the same protocol as the other group (as above)

Notes

\section{Risk of bias}

\section{Bias}

Authors' judgement

\section{Support for judgement}


Ricci 2000 (Continued)

\begin{tabular}{|c|c|c|}
\hline $\begin{array}{l}\text { Random sequence generation (selection } \\
\text { bias) }\end{array}$ & Unclear risk & $\begin{array}{l}\text { The study gave no information about gen- } \\
\text { eration of the randomisation sequence }\end{array}$ \\
\hline Allocation concealment (selection bias) & Unclear risk & $\begin{array}{l}\text { The study reported no information about } \\
\text { allocation concealment }\end{array}$ \\
\hline $\begin{array}{l}\text { Blinding of participants and personnel } \\
\text { (performance bias) } \\
\text { All outcomes }\end{array}$ & Unclear risk & $\begin{array}{l}\text { It would probably have been impossible to } \\
\text { blind the participants }\end{array}$ \\
\hline $\begin{array}{l}\text { Blinding of outcome assessment (detection } \\
\text { bias) } \\
\text { All outcomes }\end{array}$ & Low risk & $\begin{array}{l}\text { The study blinded investigators doing clin- } \\
\text { ical assessments. The personnel who took } \\
\text { the dust samples were not told about the } \\
\text { trial }\end{array}$ \\
\hline $\begin{array}{l}\text { Incomplete outcome data (attrition bias) } \\
\text { All outcomes }\end{array}$ & Unclear risk & $\begin{array}{l}\text { The study did not report the final numbers } \\
\text { of participants analysed }\end{array}$ \\
\hline Selective reporting (reporting bias) & High risk & $\begin{array}{l}\text { The study did not perform between-group } \\
\text { analyses, only within groups }\end{array}$ \\
\hline Other bias & Unclear risk & $\begin{array}{l}\text { The study described the inclusion criterion } \\
\text { as 'the extrinsic variant of } \mathrm{AD} \text {, i.e. raised } \\
\text { serum total IgE antibodies and/or the pres- } \\
\text { ence of specific IgE antibodies to foods or } \\
\text { inhalant allergens' }\end{array}$ \\
\hline
\end{tabular}

Tan 1996

Methods

Participants

Outcomes

Interventions acaricide spray and high-filtration vacuum cleaner $(\mathrm{n}=30)$ versus mite permeable cotton encasings, water with a trace of alcohol spray, and a low-filtration vacuum cleaner $(\mathrm{n}=30)$

- Severity of dermatitis score (description matched SASSAD, but not named as such)

- Body surface area affected

Notes

House dust mite reduction and avoidance measures for treating eczema (Review) 
Tan 1996 (Continued)

\section{Risk of bias}

\begin{tabular}{|c|c|c|}
\hline Bias & Authors' judgement & Support for judgement \\
\hline $\begin{array}{l}\text { Random sequence generation (selection } \\
\text { bias) }\end{array}$ & Unclear risk & The study gave no information \\
\hline Allocation concealment (selection bias) & Unclear risk & The study gave no information \\
\hline $\begin{array}{l}\text { Blinding of participants and personnel } \\
\text { (performance bias) } \\
\text { All outcomes }\end{array}$ & Unclear risk & $\begin{array}{l}\text { The report stated 'double blind', but gave } \\
\text { no information about whether this in- } \\
\text { cluded participants, personnel (other than } \\
\text { the outcome assessor), or both }\end{array}$ \\
\hline $\begin{array}{l}\text { Blinding of outcome assessment (detection } \\
\text { bias) } \\
\text { All outcomes }\end{array}$ & Low risk & $\begin{array}{l}\text { The study reported that the evaluating } \\
\text { physician (severity of eczema) was not } \\
\text { aware of the randomisation status of the } \\
\text { participants }\end{array}$ \\
\hline $\begin{array}{l}\text { Incomplete outcome data (attrition bias) } \\
\text { All outcomes }\end{array}$ & High risk & $\begin{array}{l}\text { The study only included in the final anal- } \\
\text { yses participants who finished the study. } \\
\text { Therefore, } 28 / 30 \text { in the mite impermeable } \\
\text { encasing group and } 20 / 30 \text { in the mite per- } \\
\text { meable encasings group were analysed }\end{array}$ \\
\hline Selective reporting (reporting bias) & High risk & $\begin{array}{l}\text { The groups differed in severity at baseline, } \\
\text { but this was not really dealt with in the } \\
\text { analysis. The study gave much weight to the } \\
\text { results of a subgroup analysis, but it is not } \\
\text { clear whether this was stated a priori. Also, } \\
\text { the study reports analysis of the difference } \\
\text { between groups for this subgroup analysis } \\
\text { as significant, but the confidence interval } \\
\text { crosses } 0\end{array}$ \\
\hline Other bias & Unclear risk & $\begin{array}{l}\text { The study did not state the method of di- } \\
\text { agnosis of eczema, but stated there were } \\
\text { more participants with severe eczema in } \\
\text { one group than the other }\end{array}$ \\
\hline
\end{tabular}

Terreehorst 2005

\begin{tabular}{|c|c|}
\hline Methods & Randomised, blinded parallel (2-arm) group \\
\hline Participants & $\begin{array}{l}\text { Inclusion criteria } \\
\text { - atopic eczema/dermatitis syndrome diagnosed according to the criteria of Hanifin } \\
\text { and Rajka } \\
\text { - aged } 8 \text { to } 50\end{array}$ \\
\hline
\end{tabular}


Terreehorst 2005 (Continued)

- RAST test of 2 or more, intracutaneous skin test of 0.7 of more for house dust mite, or both

- mattress must contain at least $200 \mathrm{ng} \operatorname{Der} p 1$ in a dust sample

The study randomised a total of 64 participants with eczema. It was not clear how many participants with eczema were in each group

Interventions

- mite impermeable encasings for mattress, pillow, and duvet and mite permeable encasings for mattress, pillow, and duvet

Outcomes

- Quality of life (SF 36) generic self assessment of physical and emotional health

Notes

Risk of bias

\begin{tabular}{l|l|l} 
Bias & Authors' judgement & Support for judgement \\
\hline $\begin{array}{l}\text { Random sequence generation (selection } \\
\text { bias) }\end{array}$ & Unclear risk & The paper reported no details \\
\hline Allocation concealment (selection bias) & Low risk & $\begin{array}{l}\text { There was a clear description of a remote } \\
\text { procedure that prevented the physicians } \\
\text { and participants being able to gain access } \\
\text { to or predict the randomisation sequence }\end{array}$
\end{tabular}

Blinding of participants and personnel Unclear risk (performance bias)

The paper provided a description of 'double blind', but reported very little detail

All outcomes

Blinding of outcome assessment (detection Unclear risk bias)

All outcomes

The study blinded the clinician, but did not provide enough information in the trial report to assess whether the participants, who recorded the data for the subjective outcomes, were also blinded, and because of the nature of the different interventions, it seems likely that this was not possible

Incomplete outcome data (attrition bias) Unclear risk All outcomes

The study analysed only 89/113 and 93/ 111 participants from each group and did not report how many had eczema

The study did not specify any time periods for the outcomes, so it is unclear whether the time period that the study reported for each of the outcomes matched the original trial protocol 
Terreehorst 2005 (Continued)

\begin{tabular}{|c|c|c|}
\hline Other bias & Low risk & $\begin{array}{l}\text { The eczema definition was according to the } \\
\text { Hanifin and Rajka criteria }\end{array}$ \\
\hline
\end{tabular}

anti-HDM = anti-house dust mite.

Der fIf1 = Dermatophagoides farinae.

Der $p / p 1=$ Dermatophagoides pteronyssinus.

$\mathrm{IgE}=$ immunoglobulin $\mathrm{E}$.

$\mathrm{IgG}=$ immunoglobulin $\mathrm{G}$.

$\mathrm{n}=$ number.

RAST = radioallergosorbent test.

VAS = visual analogue scale.

Characteristics of excluded studies [ordered by study ID]

\begin{tabular}{l|l}
\hline Study & Reason for exclusion \\
\hline Adham 2011 & There was only 1 intervention group \\
\hline Corver 2006 & This was a prevention of eczema study \\
\hline D'Souza 1973 & This review did not cover the intervention of immunotherapy \\
\hline Holm 2001 & $\begin{array}{l}\text { The paper did not report this as being randomised, which we confirmed via contact with the senior } \\
\text { author (Annika Scheynius) }\end{array}$ \\
\hline Kim 2005 & The paper did not report this as being randomised \\
\hline Norris 1987 & The intervention was not reduction or avoidance of house dust mite \\
\hline Sanda 1992 & The paper did not report this as being randomised \\
\hline Weber-Chrysochoou 2007 & This was not a treatment trial \\
\hline
\end{tabular}




\section{DATA ANDANALYSES}

This review has no analyses.

\section{CONTRIBUTIONSOFAUTHORS}

Link with editorial base and co-ordination of contributions from co-reviewers (HN)

Draft protocol (HN, with contributions from all)

Run search (HN)

Identify relevant titles and abstracts from searches (HN and EP)

Obtain copies of trials (HN, EP, with contributions from all)

Selection of trials (HN, EP, RB, and HW)

Extract data from trials (HN, and EP)

Enter data into RevMan (HN, and EP)

Carry out analysis (HN, LR, and EP)

Interpret data (HN, EP, RB, LR, and HW)

Draft final review (HN, with contribution from all)

Update review $(\mathrm{HN})$

\section{Disclaimer}

The views and opinions expressed therein are those of the authors and do not necessarily reflect those of the NIHR, NHS or the Department of Health, UK.

\section{DECLARATIONSOF INTEREST}

Helen Nankervis: nothing to declare.

Emma V Pynn: nothing to declare.

Robert J Boyle: "I am a co-investigator on a new trial of temperature controlled laminar airflow for treating atopic eczema http:/ /www.hra.nhs.uk/news/research-summaries/temperature-controlled-laminar-airflow-in-severe-paediatric-eczema/. This is an allergen avoidance study taking place at Imperial College, in children and adolescents with severe eczema."

Lesley Rushton: nothing to declare.

Hywel C Williams: nothing to declare.

Deanne M Hewson: nothing to declare.

Thomas Platts-Mills: nothing to declare. 


\section{SOURCES OF SUPPORT}

\section{Internal sources}

- Centre of Evidence Based Dermatology, UK.

Support and guidance

\section{External sources}

- The National Institute for Health Research (NIHR), UK.

The NIHR, UK, is the largest single funder of the Cochrane Skin Group.

\section{DIFFERENCES BETWEEN PROTOCOLANDREVIEW}

The primary outcomes both stated in the protocol that the severity scales used had to be named and validated. The reality is that with so little data available for the primary outcomes and the difficulty with defining whether an outcome severity scale has been suitably validated, we removed the requirement for validated severity scales.

In the protocol, we had stated that we would search excluded studies for adverse effects. We removed this statement as by definition, they would not be relevant for this review. 